(III norden

\title{
Input to TWG on BAT Candidates for Breweries
}

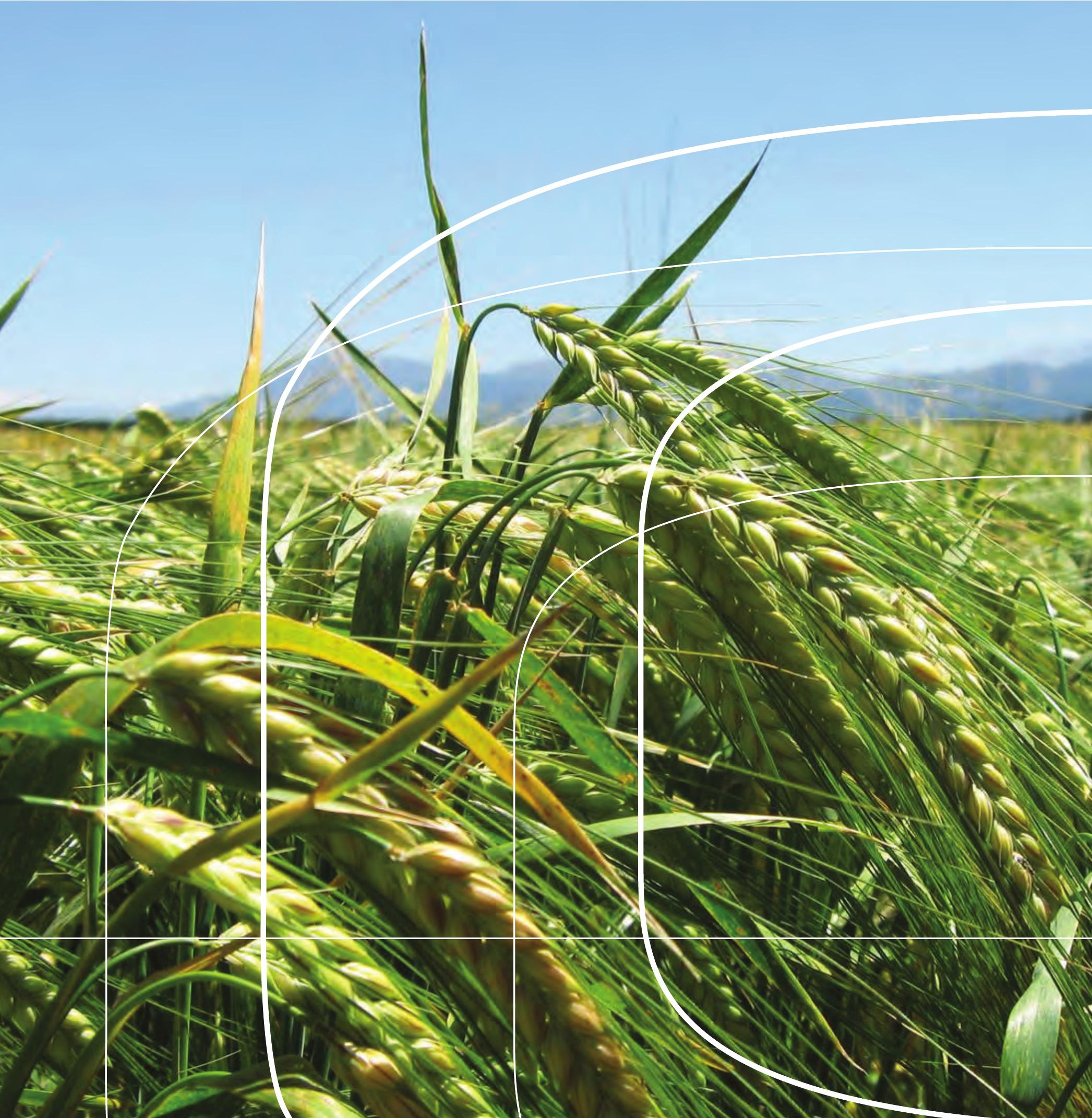


enorden 



\section{Input to TWG on BAT Candidates for Breweries}

Jan Holmegaard Hansen, COWI AS (Project Manager) Axel Grøndahl Kristiansen, Scandinavian School of Brewing Kim Lau Johansen, Scandinavian School of Brewing Christian Mou, COWI AS

Claes-Göran Johansson, Swebrew AB

John Sørensen, COWI AS

TemaNord 2011:547 


\section{Input to TWG on BAT Candidates for Breweries}

TemaNord 2011:547

ISBN 978-92-893-2245-4

(C) Nordic Council of Ministers, Copenhagen 2011

Cover photo: Axel Grøndahl Kristensen

This publication has been published with financial support by the Nordic Council of Ministers. But the contents of this publication do not necessarily reflect the views, policies or recommendations of the Nordic Council of Ministers.

www.norden.org/en/publications

\section{Nordic co-operation}

Nordic co-operation is one of the world's most extensive forms of regional collaboration, involving Denmark, Finland, Iceland, Norway, Sweden, and Faroe Islands, Greenland, and Åland.

Nordic co-operation has firm traditions in politics, the economy, and culture. It plays an important role in European and international collaboration, and aims at creating a strong Nordic community in a strong Europe.

Nordic co-operation seeks to safeguard Nordic and regional interests and principles in the global community. Common Nordic values help the region solidify its position as one of the world's most innovative and competitive.

Nordic Council of Ministers

Ved Stranden 18

DK-1061 Copenhagen $\mathrm{K}$

Phone (+45) 33960200

www.norden.org 


\section{Content}

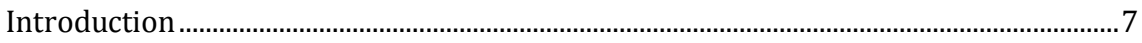

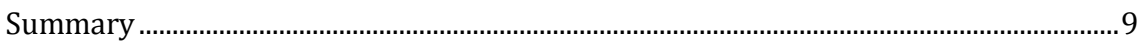

Identification of new BAT candidates................................................................................ 11

1. BAT Candidate no. 1 - 100\% barley beer brewing.................................................... 15

1.1 Introduction......................................................................................................... 15

1.2 Applied processes and techniques .................................................................. 16

1.3 Emissions and consumption figures.............................................................. 17

1.4 Environmental benefits......................................................................................... 17

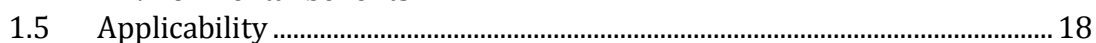

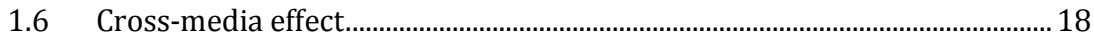

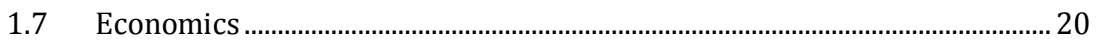

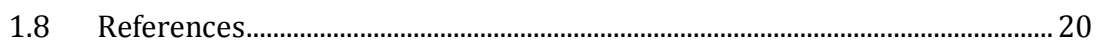

2. BAT Candidate no. 2 - Barley beer brewing …….................................................... 21

2.1 Introduction.................................................................................................... 21

2.2 Applied processes and techniques ................................................................... 21

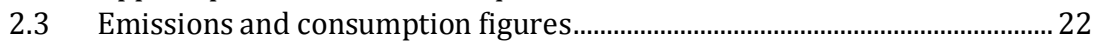

$2.4 \quad$ Environmental benefits.............................................................................. 22

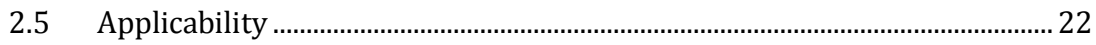

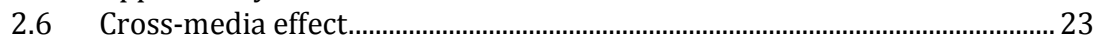

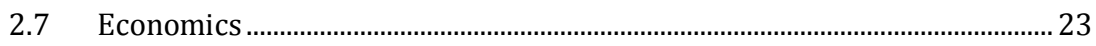

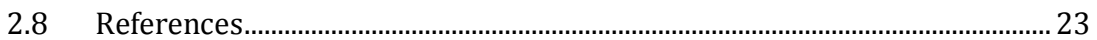

3. BAT Candidate no. 3 - Iso-mixer fermentation system ……………........................ 25

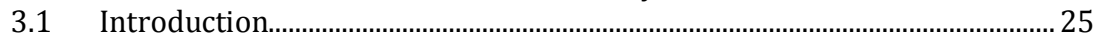

3.2 Applied processes and techniques ................................................................ 25

3.3 Emissions and consumption figures........................................................... 25

3.4 Environmental benefits.................................................................................... 26

3.5 Applicability ........................................................................................................ 26

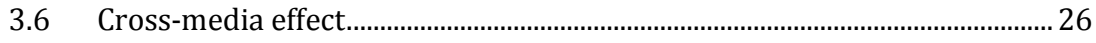

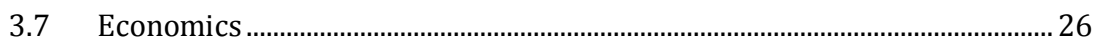

3.8 References............................................................................................................ 26

4. BAT Candidate no. 4 - Integrated energy system in $\mathrm{CO}_{2}$ recovery plant.................27

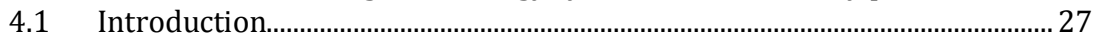

4.2 Applied processes and techniques................................................................. 27

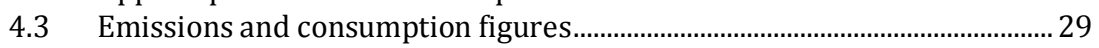

4.4 Environmental benefits..................................................................................... 29

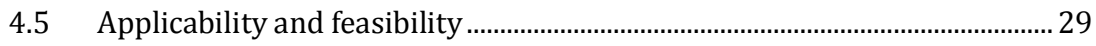

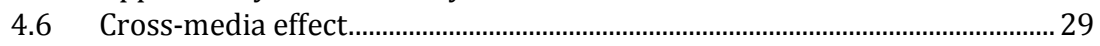

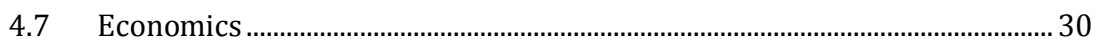

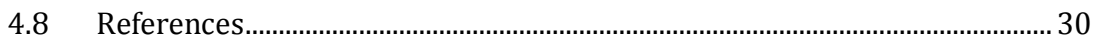

5. BAT Candidate no. 5 - Optimization of energy consumption in the

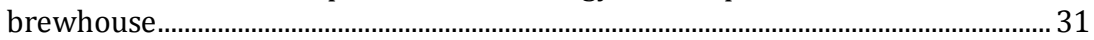

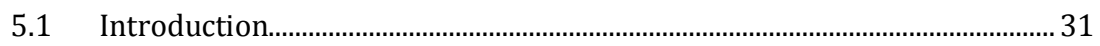

5.2 Applied processes and techniques .................................................................. 31

5.3 Emissions and consumption figures................................................................. 33

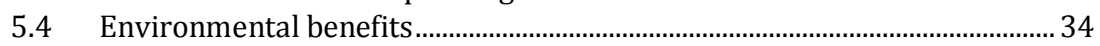

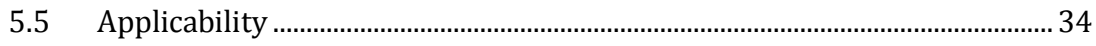

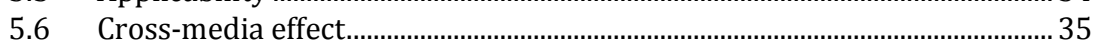

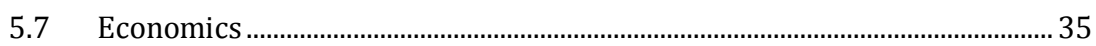

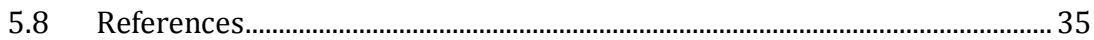


6. BAT Candidate no. 6 - The double malt kiln................................................................ 37

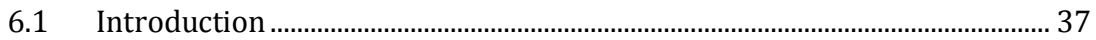

6.2 Applied processes and techniques ............................................................. 37

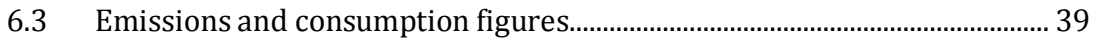

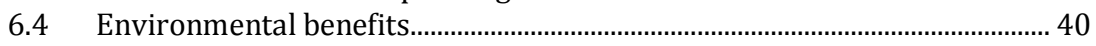

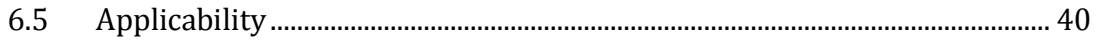

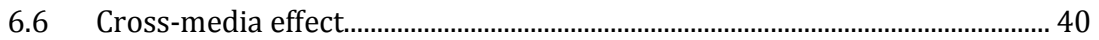

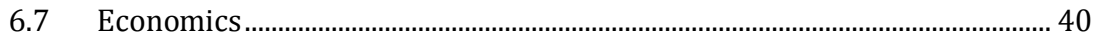

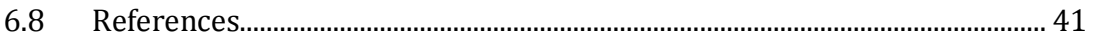

7. BAT Candidate no. 7 - Use of non-fossil fuel based energy at malt house

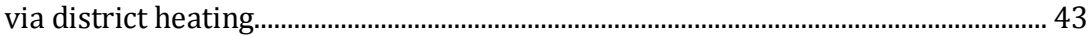

7.1 Introduction ........................................................................................................... 43

7.2 Applied processes and techniques ................................................................ 43

7.3 Emissions and consumption figures................................................................ 43

7.4 Environmental benefits.................................................................................... 44

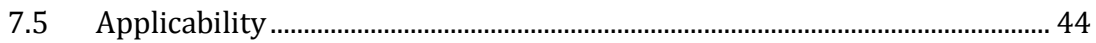

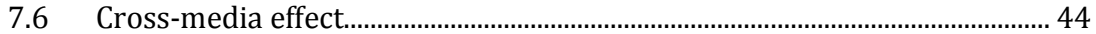

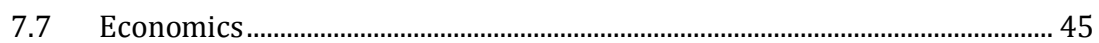

7.8 References.......................................................................................................... 45

8. BAT Candidate no. 8 - Brewery surplus yeast, rest beer and soft-drinks

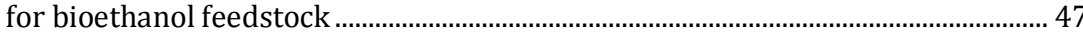

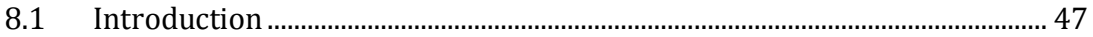

8.2 Applied processes and techniques....................................................................... 47

8.3 Emissions and consumption figures............................................................ 49

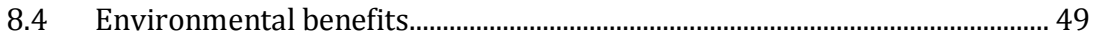

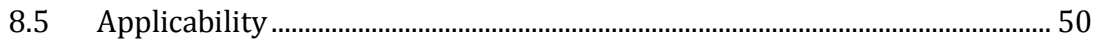

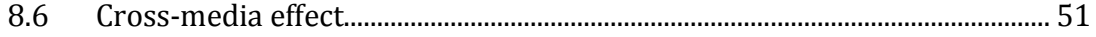

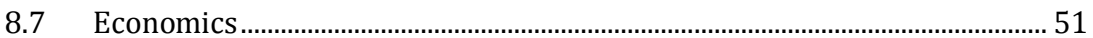

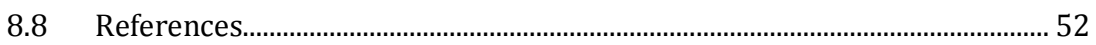

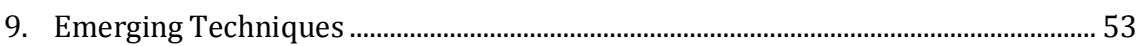

9.1 External cooling of the fermentation tank ..................................................... 53

9.2 Electro Chemical Activation (CIP) ………...................................................... 55

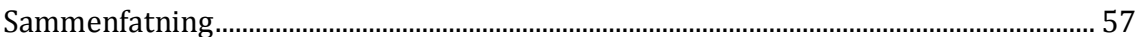




\section{Introduction}

The Nordic Council of Ministers, the BAT Group under the Nordic SCP (also called HKP) Group has requested COWI AS, Denmark with subconsultants (the Scandinavian School of Brewing, Denmark and Swebrew AB, Sweden) to prepare a report on inputs to TWG (Technical Working Group) on review of the BREF for Food, Drink and Milk Industries, 2006 as a joined contribution from the Nordic countries.

\section{Objective}

The overall objective of the report is to present new BAT (Best Available Techniques) candidates for the breweries, malting companies and soft drink producers not included in the BREF for FDM Industries, 2006. The presentation of new BAT will be presented as cases based on data on resource consumption and emissions provided by the breweries and malting companies taking part of the project.

\section{Scope}

The Nordic countries have a number of larger breweries and malting companies. An overview of IPPC relevant breweries, malting companies and soft drink producers in the Nordic countries are given in table 1. Several breweries do also produce soft drinks as an integrated part of the brewery. In some cases as an integrated part and in other cases with possibilities to distinguish between beer and soft drink productions.

All breweries and malting companies have a production capacity exceeding 300 tons per day or 1,100,000 hl per year.

\begin{tabular}{|c|c|c|c|}
\hline Country & Breweries & Malting companies & $\begin{array}{l}\text { Soft drink } \\
\text { producers }\end{array}$ \\
\hline Denmark & $\begin{array}{l}\text { Carlsberg, Frederecia (including Coca } \\
\text { Cola), Royal Unibrew, Faxe } \\
\text { (including Pepsi), Harboe Bryggeri, } \\
\text { Skælskør (including soft drinks) }\end{array}$ & $\begin{array}{l}\text { DMG, Vordingborg (115-120,000 t/year) } \\
\text { Fuglsang Maltfabrik (150,000 t/year), } \\
\text { Haderslev og Thisted }\end{array}$ & \\
\hline Sweden & Carlsberg Sverige & $\begin{array}{l}\text { Viking Malt, Halmstad ( } 370.000 \text { t/year: } \\
\text { Sweden, Finland and Lithuania) }\end{array}$ & $\begin{array}{l}\text { Coca Cola, } \\
\text { Haninge }\end{array}$ \\
\hline Norway & Ringnes (including Pepsi) & None & Coca Cola \\
\hline Finland & $\begin{array}{l}\text { Sinebrychoff, Kerava (including Coca } \\
\text { Cola), Hartwall, Lahti (including Pepsi) }\end{array}$ & Viking Malt, Lathi Raisio & \\
\hline
\end{tabular}

\section{Approach}

The Associations of Breweries in the Nordic countries have been invited to take part in the project through a dispatched letter of invitation. The Associations have kindly requested member breweries to take part in the project and the team of consultants has also directly invited breweries to participate. 
Consultants have visited a number of breweries and malting companies, collected and processed data and finally drafted the BAT cases in the report.

\section{Team of consultants}

The following consultants have contributed to the report:

- Jan Holmegaard Hansen, COWI AS (Project Manager)

- Axel Grøndahl Kristiansen, Scandinavian School of Brewing

- Kim Lau Johansen, Scandinavian School of Brewing

- Christian Mou, COWI AS

- Claes-Göran Johansson, Swebrew

\section{BAT Group}

The BAT project has been follow and commented by the Nordic BAT Group. The members of the BAT Group are:

- Jard Gidlund, Naturvårdsverket, Swedish Environmental Protection Agency (Chair)

- Tina Schmidt, Miljøstyrelsen, Danish Environmental Protection Agency

- Jaakko Kuisma, Regionalförvaltningsverket i Södra Finland, Regional State Administrative Agency for Southern Finland

- Jákup í Horni, Umhvørvisstovan, Environment Agency of Faroe Islands

- Sigurdur Ingason, Umhverfisstofnun, Environment Agency of Iceland

- Egil Strøm, Klima- og forurensningsdirektoratet, Climate and Pollution Agency, Norway

- Susanne Särs, Ålands miljö- och hälsoskyddsmyndighet, Environmental and Health Protection Agency of the Aland Islands

\section{Anonymity}

Some of the information related to new BAT is confidential. Consequently, the breweries are of this reason not willing to disclose information, which could give competitors insight on where one brewery has been able to reduce production costs and improved the competitiveness.

The consultants have after consultation with the BAT Group granted the participating breweries anonymity in the cases, when requested by the breweries.

\section{Thanks}

The team of consultants hereby express our sincere thanks to all companies, associations and persons, who have contributed to the report. A special thank to the companies, who has taken time to see the consultants and for all the valuable data and information, the team has received. Without this support it would not have been possible to reach the expected outcome. 


\section{Summary}

The report presents new BAT (Best Available Techniques) candidates for larger and IPPC relevant breweries, malting companies and soft drink producers identified within the Nordic brewery sector.

Larger and IPPC relevant breweries have production capacity exceeding 300 tons per day or 1,100,000 hl per year. The number of larger breweries and malting companies in the Nordic countries is 7 and 3 companies respectively.

The report is prepared as a joint Nordic contribution to the Technical Working Group and is proposed to be used when a review of the BREF for Food, Drink and Milk Industries from 2006 is launched.

Dissemination of new ideas and technologies are mainly spread through technology suppliers and consultants. In some cases this dissemination goes very fast. However, from the time of introduction of a new BAT candidate to a full documentation it might take some time. Mainly due to these reasons it has been a challenge to identify BAT candidates, which are sufficiently tested and have fully documented results without being known by too many breweries. The identification of new BAT candidates in this report has followed some priorities of which the origin of the new BAT candidate primarily should be in one of the Nordic countries.

The BAT described in the report are related to a number of resource saving and optimisation solutions, e.g. substitution of raw materials and processes, savings of energy, water and chemicals, use of non-fossil fuel plus production of renewable energy from waste products.

8 potential new BAT candidates and 2 emerging techniques are included in the report: The new BAT candidates are:

- $100 \%$ barley brewing (raw material substitution and energy saving)

- Barley beer brewing (water and energy saving)

- ISO-mixer fermentation system (productivity enhancement)

- Integrated energy system in $\mathrm{CO}_{2}$-recovery plant (Liquivap, energy saving)

- Optimization of energy consumption in the brewhouse (reduction and optimisation of energy consumption)

- The double malt kiln (energy saving)

- Use of non-fossil fuel based energy at malt house (saving energy and use of non-fossil fuel)

- Brewery surplus yeast, beer and soft drink rests for bioetahnol feedstock (reduction of wastewater load and energy saving) 
The 2 emerging techniques are:

- External cooling of the fermentation tank (energy saving)

- Electro Chemical Activation (saving chemicals, energy and water)

All BAT candidates are described by the following parameters: applied processes and techniques, emissions and consumptions figures, environmental benefits, applicability, cross-media effect, economics and references. 


\section{Identification of new BAT candidates}

The key environmental issues for the food, drink and milk industries, including the brewing sector include primarily water and energy consumption, waste water generation and to some extent also solid waste, noise and odour generation. Focus has been given to key environmental issues when new BAT candidates are identified.

Several BAT not mentioned specifically in the BREF have been tested partly or fully in many EU countries, including in the Nordic countries (Reference Document on Best Available Techniques in the Food, Drink and Milk Industries, Integrated Pollution Prevention and Control, EUCommission, August 2006). Some of those BAT will not be new to many breweries in the EU countries.

Combined with a fast dissemination of new ideas and technologies, mainly through technology suppliers and consultants, it has been a challenge to make a clear cut, including only new and relevant BAT candidates.

To be able to identify new BAT candidates, which are relevant for this document, not know of too many companies and which are addressing the key environmental issues in the food, drink and milk industries, the following priorities has been taken to identify new BAT candidates:

- BAT, which (primarily) are developed or has its origin in the Nordic countries

- BAT, which address consumption of water and energy and emission of wastewater.

- BAT, which can be quantified by consumption data or/and emissions

- BAT, which are economically and technically viable taking into consideration the costs and advantages

An overview of new BAT candidates identified and selected as potential new BAT candidates are included in the list given in the table 1. 
Table 2: Overview of identified potential new BAT candidates to be described.

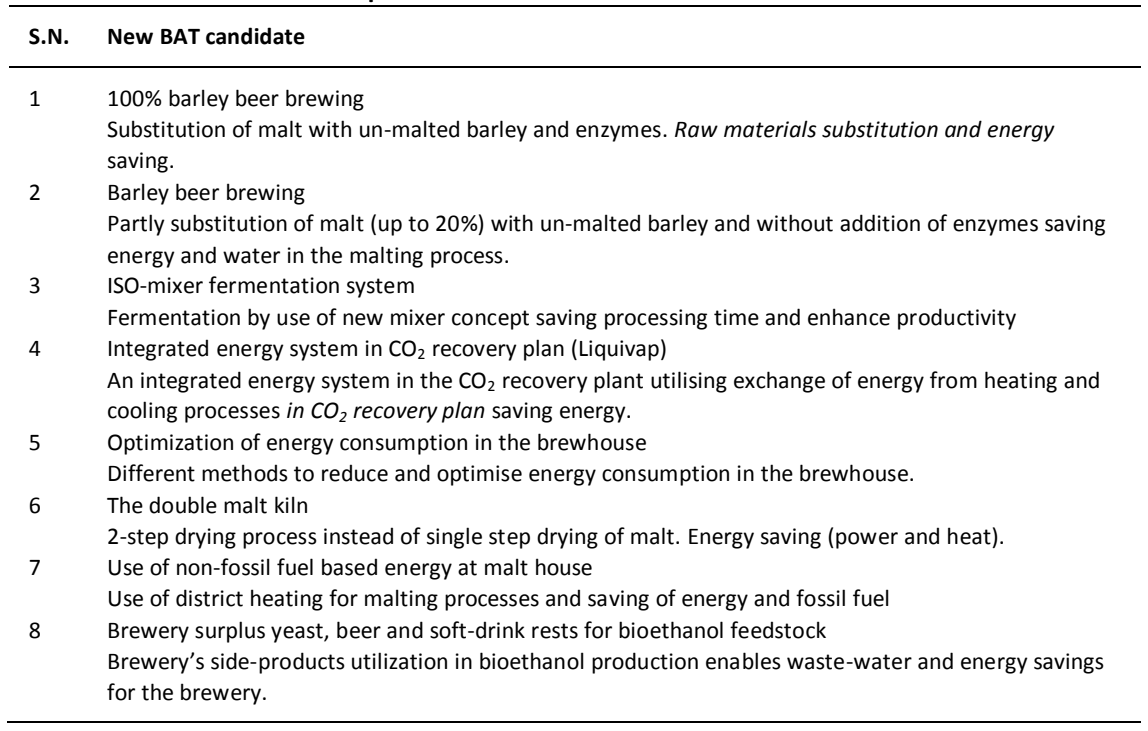

BAT candidate no. 1 is documented at one brewery in the Nordic countries. The most significant change in the process flow is that malting activities at the malting house are eliminated. Instead are barley and exogenous enzymes utilised.

BAT candidate no. 2 is a barley brewing process with partly substitution of malt and without addition of exogenous enzymes. Raw material, water and energy are saved in the malting process.

BAT candidate no. 3 is a relatively new mixing system for fermentation tanks reducing and fermentation and cooling time. This system can be combined with an external cooler (heat exchanger) reducing cooling energy further. No data on the external cooling system are made available, why this BAT candidate is described under the section "Emerging Techniques".

BAT candidate no. 4 is based on a technique which integrates two energy systems in the $\mathrm{CO}_{2}$ recovery plant utilising exchange of energy from heating and cooling processes. Huge energy savings are documented at the $\mathrm{CO}_{2}$ recovery plant at one brewery in the Nordic countries.

BAT candidate no. 5 consists of 4 methods to reduce and optimise the consumption of energy in the brewhouse leading to energy savings.

BAT candidate no. 6 uses a double malt kiln or a 2-step drying process instead of a single process malt kiln. This BAT candidate saves energy (power and heat).

BAT candidate no. 7 uses district heating for malting processes. The energy is produced at an external energy plant based on biomass, waste and supplemented by fossil fuels.

BAT candidate no. 8 is a brewery solution using surplus yeast, beer and soft-drink rests for bioethanol feedstock. Brewery's side-products utilization in bioethanol production enables waste-water and energy savings for the brewery. 
A BAT candidate called "Electro Chemical Activation" is a cold cleaning method, which has recently been introduced by some breweries in the Nordic countries. Consequently, long-term and reliable data are not available and this BAT candidate can at the moment not be documented. This BAT candidate is shortly described under section "Emerging Techniques". 



\section{BAT Candidate no. $1-100 \%$ barley beer brewing}

\subsection{Introduction}

Traditional beer brewing is based on malt, additional cereals, hops, yeast and water. A new beer brewing technology is now demonstrated and documented. The new technology substitutes malt by barley and industrial enzymes. This process is referred to as $100 \%$ barley beer brewing.

The idea is not completely new. Industrial enzymes have routinely been used as supplement to malt enzymes for quite some time (see also case no. 2). The new aspect of the technology is that malted barley is substituted by raw barley and industrial enzymes.
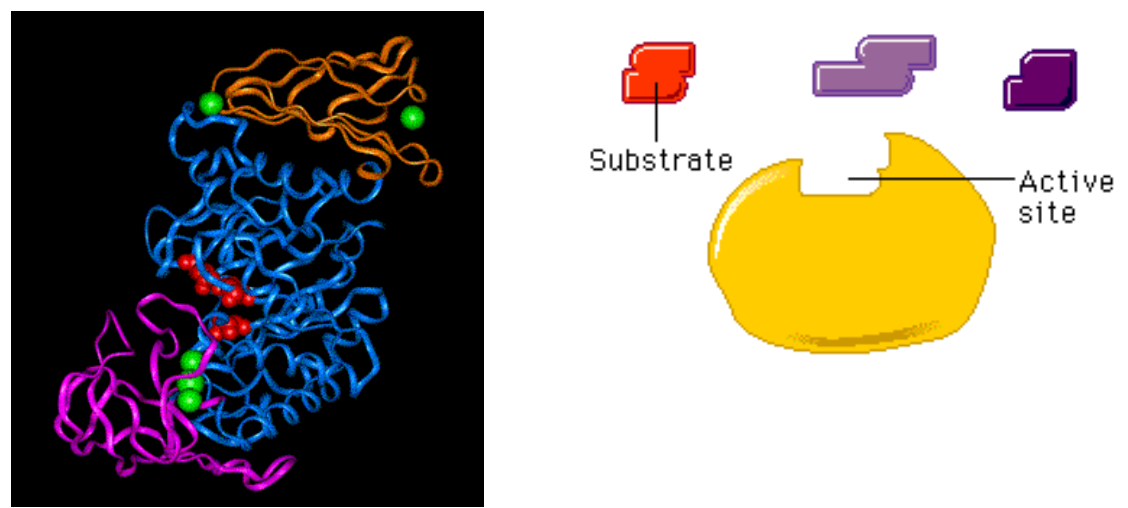

Figure 1.

Malt is germinated barley and during the malting process natural enzymes are produced. The enzymes are responsible for the conversion process of starches in the malt to fermentable sugars. By addition of raw barley and industrially produced enzymes to the brewing process, malt can be substituted. Barley substitutes in the new technology malt as the sugar source and industrial enzymes are added to supplement the natural production of enzymes produced during malting. Consequently, the malting process can be eliminated.

Hereby, water and energy consumption at the malting plant is avoided. A Life Cycle Assessment (LCA) is conducted to analyse the environmental impacts of the new technology compared with traditional maltbrewing processes. The LCA shows positive environmental benefits in all investigated impact categories. The commercial enzyme used is Ondea ${ }^{\circledR}$ 
Pro. Data from the LCA is presented later in this BAT case under emission and consumption figures.

\subsection{Applied processes and techniques}

The description of applied processes and techniques in 100\% barley brewing is done by comparison with traditional malt-brewing. The reason is that there are so many similarities and only some few differences.
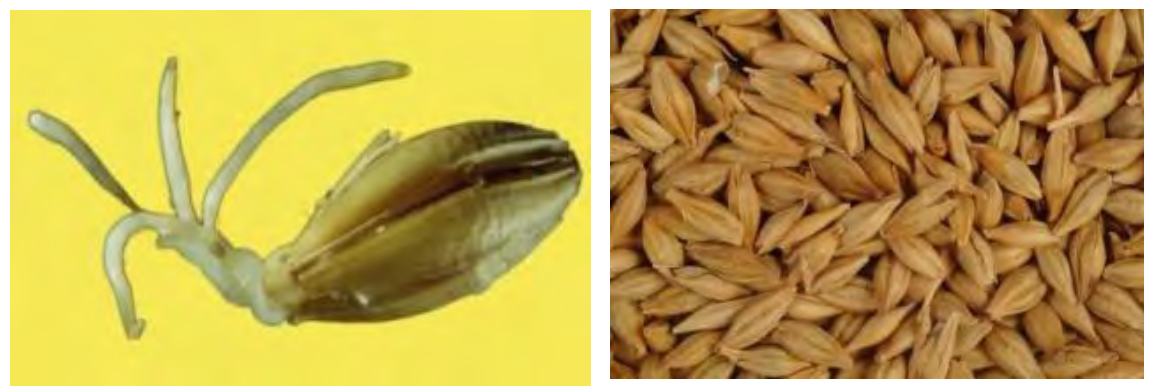

Photo 1.

The main difference and similarity are that $100 \%$ barley beer brewing has no malting process and that mash filtration is identical in both processes.

The same standard brewing equipment and standard processes are used in $100 \%$ barley beer brewing, including use of the same mash filter or lauter tun.

The production process flow charts of the two technologies compared in this BAT case are illustrated in the figure.

\section{Malt-based beer brewing}

\section{$100 \%$ barley beer brewing}

\section{Barley}

Figure 2.

The Ondea brewing concept allows the strict malting barley specifications to be broadened without compromising the final beer quality. Consequently, this allows the direct use of local crops, making beer production more sustainable. This benefit primarily arises as the Ondea Pro enzymes 
have superior activities and better heat stability than the malt enzymes, and due to the fact that the parameters necessary for a successful malting process (e.g., germination energy, water sensitivity, relationship between cytolytic and proteolytic degradation) are of less importance.

Milling process is similar and a hammer mill is used in the case brewery. Barley is harder than malt, which leads to a higher electricity consumption and more frequent change of the steel hammer.

Mashing process differs with addition of more and a specific enzyme mixture (Odea ${ }^{\circledR}$ Pro) in $100 \%$ barley brewing compared with a smaller amount of enzymes to the traditional malt brewing process. The enzymes added are working in a synergy with the enzymes naturally released from the barley.

The mash is heated in steps, which are different in the two different processes due to the use of different enzymes. In mash filtration no changes has been observed between the two processes.

\subsection{Emissions and consumption figures}

An LCA has compared $100 \%$ barley beer brewing with conventional malt beer brewing at Harboes Bryggeri (a Danish IPPC regulated brewery) through the processes: barley production, malting, milling, mashing and wort boiling. The results of the LCA are described in section 1.6 Cross-media effects.

The significant changes of emissions and consumption figures are: consumption of barley and energy and the emission of $\mathrm{CO}_{2}$.

The consumption of barley is reduced by $700 \mathrm{~kg}$ (or 7\%) per functional unit (10 tons of malt) by using $100 \%$ barley beer brewing instead of traditional malting.

The consumption of energy is reduced by $136 \mathrm{MJ}$ per ton of malt substituted by using $100 \%$ barley brewing instead of traditional malt brewing.

The consumption of water might be slightly reduced, but data is not available to finally assess if a water reduction is achieved.

The $\mathrm{CO}_{2}$ reduction is estimated to $1,740 \mathrm{~kg} \mathrm{CO}$ eq. per functional unit (10 tons of malt) or $174 \mathrm{~kg} \mathrm{CO} 2$ eq. per ton of malt replaced by barley.

\subsection{Environmental benefits}

The environmental benefits of $100 \%$ barley brewing compared to traditional malt brewing originate from elimination of the malting process and are primarily:

- Reduced energy consumption, which results to reduced emission of $\mathrm{CO}_{2}$ 
- Reduced barley consumption

The water consumption might be reduced, but a full data set is not available to finally assess water consumption. Saved water for malting process might be outbalanced by water consumption for production of the enzyme mixture.

Shifting form traditional malt brewing to $100 \%$ barley brewing will improve all assessed LCA categories: acidification, nutrient enrichment (eutrophication), photochemical ozone formation, energy consumption and use of agricultural land.

\subsection{Applicability}

The new brewing technology substituting malt with barley and enzymes can be applied everywhere. Tests have shown that the taste of $100 \%$ barley brewing is similar to malted beer. However, many breweries are hesitant to use addition of enzymes to their brewing process.

Data for Danish barley is used in the conducted LCA. If data on German, French, Spanish, or Swiss barley is applied, the results for global warming and energy consumption stay more or less the same.

\subsection{Cross-media effect}

The LCA has compared $100 \%$ barley beer brewing with conventional malt beer brewing. The functional unit was 7 tons of extract after wort boiling enough to produce $680 \mathrm{hl}$ of beer (alcohol strength of $4.6 \%$ by volume). 10 tons of malt and 25 tons of water are used to produce the functional unit. $4 \mathrm{~kg}$ enzymes are added.

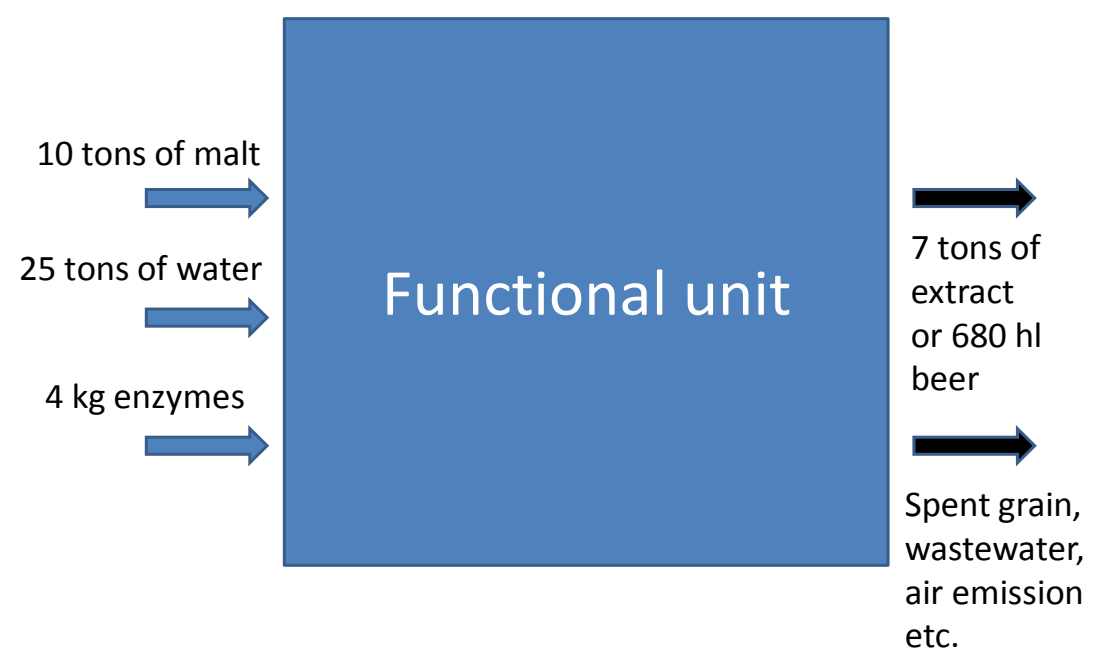

Figure 3. 
Heat, electricity and water consumption for the production of the industrial produced enzyme are together with produced waste included in the LCA study, but data is not disclosed due to confidential consideration.

The ISO standards for LCA (14040 and 14044) have been used and an external critical review has been conducted.

Only significant criteria are included in the LCA comparison. Criteria of in-significant importance are cut-off.

The net reductions in the environmental impacts per functional unit (10 tons of malt) are given in the table below.

\begin{tabular}{lrr} 
Table 3. & \\
\hline Impact category & Net reduction & Unit per $\mathbf{1 0}$ tons of malt \\
\hline Global warming & 1,740 & $\mathrm{~kg} \mathrm{CO}_{2}$ eq. \\
Acidification & 3.3 & $\mathrm{~kg} \mathrm{SO}_{2}$ eq. \\
Eutrophication & 3.5 & $\mathrm{~kg} \mathrm{PO}_{4}^{-3}$ eq. \\
Photochemical ozone formation & 260 & $\mathrm{~g} \mathrm{C}_{2} \mathrm{H}_{4}$ eq. \\
Fossil energy & 1.36 & $\mathrm{GJ}$ \\
Agricultural land use & 1,380 & $\mathrm{~m}^{2}$ year \\
\hline
\end{tabular}

Some activities result in $\mathrm{CO}_{2}$ reductions and others in increases. Energy for malting (heat, electricity and water) has a reduction of $1,590 \mathrm{~kg} \mathrm{CO}_{2}$ eq. and $441 \mathrm{~kg} \mathrm{CO} 2$ eq. for saved barley. Addition of the industrial enzymes in mashing process accounts for an increase of $301 \mathrm{~kg} \mathrm{CO}_{2}$ eq. Transportation, milling and boiling have a minor impact on energy consumption over a life cycle.

The aggregated $\mathrm{CO}_{2}$ reduction is as shown in the table above $1,740 \mathrm{~kg}$ $\mathrm{CO}_{2}$ eq. per functional unit (10 tons of malt) or $174 \mathrm{~kg} \mathrm{CO}$ eq. per ton of malt replaced by barley. This corresponds to a $\mathrm{CO}_{2}$ reduction of $8.4 \mathrm{~g}$ CO2 eq. per can of beer ( $33 \mathrm{cl}, 4.6 \%$ alcohol by volume) of malt replaced with barley.

The output of boiled wort is $600 \mathrm{~kg}$ larger for a batch of barley brewing than for traditional malt-based brewing. This means that boiling of traditional wort consumes more energy $(1.36 \mathrm{GJ}=600 \mathrm{~kg} \times 2,270 \mathrm{~kJ} / \mathrm{kg})$ than $100 \%$ barley brewing per functional unit (10 tons of malt) to produce the same amount of wort. $2,270 \mathrm{~kJ} / \mathrm{kg}$ is the evaporation enthalpy for water.

$25 \mathrm{~kg}$ of an industrial enzyme mixture (Ondea ${ }^{\circledR}$ Pro) are added in the $100 \%$ barley brewing process instead of $4 \mathrm{~kg}$ of enzymes added to traditional malting brewing.

An insignificant reduction in consumed amount of hop extract is used for barley brewing.

The consumption of barley is reduced by $700 \mathrm{~kg}(7 \%)$ per functional unit (10 tons of malt) by using the barley directly instead of malting it (4\% moisture) is replaced by 11 ton barley (14\% moisture). During malting $5-10 \%$ of the dry weight is lost to aspiration and physical loss (roodlets, agrosperies etc. Consequently, the agricultural land use is reduced shifting to $100 \%$ barley brewing. 
Data for malt production has been used from an energy efficient malting plant. If malt is used from less energy efficient malting plant, the reductions will be higher.

\subsection{Economics}

With a raw material price difference of about 100 Euro per ton malt $(=$ 1.1 ton barley) the total savings will be about 500 Euro per hl final $100 \%$ barley beer. The difference may change over the time with the raw material prices.

Beside savings on raw material costs there will be savings on energy consumption (1.36 GJ/functional unit).

\subsection{References}

Novozymes AS Denmark, http://www.novozymes.com

Direct link to Life Cycle Assessment:

http://www.novozymes.com/en/sustainability/sustainable-solutions/life-cycleassessments/Documents/BarleyBeer.pdf

Harboe Breweries AS, Denmark http://www.harboe.com 


\section{BAT Candidate no. 2 - Barley beer brewing}

\subsection{Introduction}

Traditional beer brewing is based on malt, additional cereals, hops, yeast and water. It is now also possible to use un-malted barley as partly replacement of malt. The new barley brewing process has now been demonstrated and documented at Nordic breweries / $1 /$. This process is referred to as partly substitution of malt with barley for beer brewing.

The idea in the BAT candidate is a variation of the idea of using adjuncts (unmalted grain such as corn, rice etc) as partly malt replacement. Up to $20 \%$ of malt can be substituted without major process problems and addition of external enzymes. Use of external enzymes can reduce $50 \%$ or more of the malt.

The BAT candidate described is based on less than $20 \%$ substitution of malty and without addition of external enzymes. If the amount of barley used is not above $20 \%$ of the total grist (grain without chaff), the existing equipment and process may be used, as long as good quality malt is used for the malt part of the grist.

\subsection{Applied processes and techniques}

\section{General}

De-husked barley or normal barley may be used for the barley brewing process:

- Cleaning of normal barley is necessary by the supplier is required, or barley cleaning equipment is needed at the brewery. The brewery will often have the necessary equipment available for malt cleaning during transfer from silo to brewhouse

- Barley should be mashed in together with the malt or before in order, that enzymes present in the malt may start to attack the starch in the barley as soon as possible

- A flavour stability challenge may be created, if barley is mashed in after the malt 


\section{Process performance}

- Mashing time and temperatures should be similar to all malt process, but may have to be adjusted to achieve the desired Real Degree of Fermentation (RDF)

- Fermentation, maturation and filtration processes do not need adjustments other than increased sampling, untill the process has been tested

\section{Limits}

- The process is recommended with up to $20 \%$ barley without enzymes, and in some cases the amount may be further increased. By $50 \%$ barley or more, external enzymes are necessary to compensate lack of beta and alfa amylase activities in the grist to degrade starch

- The flavour could become more straw like

- Run-off in lauter tun could become slower

\section{Required Equipment:}

- Dry or wet milling system

- Existing mills might be capable, if the barley is mixed with the malt

\section{Potential Investment:}

- Barley intake \& cleaning equipment - if not already in place

- Silo for barley (but a former malt silo will do fine)

- Barley milling system, if existing system is not capable

\subsection{Emissions and consumption figures}

The electricity consumption for the mill is expected to increase, as the barley is harder to mill than the malt. No data is yet available to quantify the economical impact, but it assessed to be marginal.

\subsection{Environmental benefits}

As only $80 \%$ of the barley gets malted, a proportional reduction in consumption of water, heat and electricity in the malting process is achieved, and this is without routinely introduction of external enzymes for the mashing process.

\subsection{Applicability}

The technology is applicable in most breweries, as analytical data and flavour for quality of the finished beer is similar to all malt beers. 
The breweries interested must be prepared to keep one more cereal in stock in silos and to accept a slight increase in speed of wear in the mill(s).

\subsection{Cross-media effect}

No negative environmental effects are foreseen, as no external enzymes (requiring external energy for manufacturing) are applied. The resulting spent grains from the brewhouse carries similar value as cattle feed as all malt spent grains.

\subsection{Economics}

The price ratio barley/malt is not permanent, although barley should always be some $30 \%$ cheaper than malt. The incentive for partly replacement of barley may therefore fluctuate.

- There do not seem to be major process problems - and need for capital expenditure - using up to $20 \%$ barley instead of malt

- No data is yet available to quantify the economical impact by part replacement of malt with barley. However, with an assumption that barley is $30 \%$ cheaper than malt, the general saving obtained should become $1 / 3$ of $20 \%$ of the total grist price compared with $100 \%$ malt, i.e. $93 \%$ of the previous all malt costs for the brewing grists

- The barley price may be close to the price for maize/rice, and the economically difference between cost for barley and cost for maize/rice should be monitored

- Brewers are advised to develop a flexible recipe concept, i.e. being able to shift between barley/malt, all malt or maize/malt brewing grists

\subsection{References}

Scandinavian School of Brewing, Master brewer curriculum: module 1 lecture, August-September, 2010. http://brewingschool.dk 



\section{BAT Candidate no. 3 - Iso- mixer fermentation system}

\subsection{Introduction}

Introduction of forced mixing in fermentation tanks by use of rotary jet mixers reduces the processing and cooling time. The fermentation capacity is hereby maximised and a reduction of the operational cost is achieved.

\subsection{Applied processes and techniques}

Alfa Laval has developed a new fermentation mixer system called Isomixer, which has been introduced to some Nordic breweries. The system is using a rotary jet mixer, which force a much better mixing in the fermentation tank. Previously it was assumed that $\mathrm{CO}_{2}$ produced was sufficient to stir the tank and avoid yeast to settle. Studies have now shown that processing and cooling times can be reduced by up to $30 \%$.

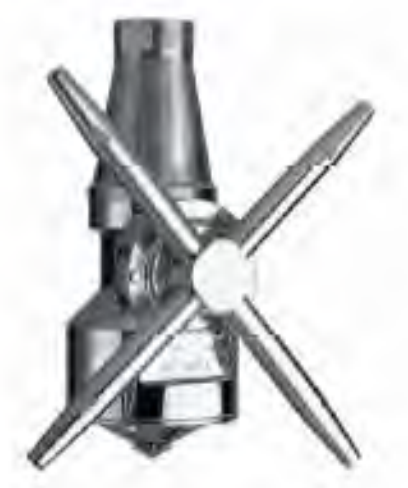

Photo 2.

\subsection{Emissions and consumption figures}

A combination of the Iso-mixer system with external cooling via a heat exchanger will make it possible to redesign fermentation tank and avoid cooling zones in the tank. Instead the fermentation tank should be well insulated. 
Unfortunately, data from the use of the Iso-mixer and in combination with the external cooling has not been available for this report.

\subsection{Environmental benefits}

The environmental benefits using the combined mixer and external cooling system will be reduced emission from production of the cooling energy.

Using the Iso-mixer system alone no changes in the cooling energy is expected. However, using the iso-mixer a higher yield of alcohol will be gained, which allows the brewery to increase production. This is a higher productivity solution with a better utilisation of the raw materials. The savings are reduced raw material utilisation and reduced transportation energy of raw materials.

\subsection{Applicability}

Every brewery will be able to use this technology.

\subsection{Cross-media effect}

The Iso-mixer pump consumes electricity to operate. The supplier and the breweries using the system do no have any data on how much extra electricity is required. The reasons are according to the supplier that it is difficult to estimate and especially because the extra energy cost is insignificant compared to the increased productivity and cost savings introducing the Iso-mixer system.

\subsection{Economics}

Alfa Laval has calculated that for a 2 million hl/year brewery introducing jet mixer technology requires an investment of less than $30 \%$ of the cost of installing new fermenters, equal to a saving more than 2 million Euros.

Using the combined mixer and external cooling system will save cost for cooling energy, processing time and make fermentation tanks much cheaper.

\subsection{References}

www.alfalaval.com 


\section{BAT Candidate no. 4 - Integrated energy system in $\mathrm{CO}_{2}$ recovery plant}

\subsection{Introduction}

Large breweries more and more rely on supplies of high quality carbon dioxide. This $\mathrm{CO}_{2}$ is either purchased in liquid form in bulk or generated on site in a $\mathrm{CO}_{2}$-recovery plant. In order to use the liquid $\mathrm{CO}_{2}$, it has to become evaporated and distributed to the point of use in the brewery.

The evaporation requires thermal energy, therefore the vaporised $\mathrm{CO}_{2}$ increases in temperature, as it cools the surrounding air. A new technique allows for reuse of the cooling energy in the evaporated $\mathrm{CO}_{2}$ to cool another cooling media. The technique is an integrated energy system in the $\mathrm{CO}_{2}$ recovery plant utilising exchange of energy from heating and cooling processes.

Similar systems are developed in Denmark and in the Netherlands and used already in a few breweries. One installation is at the moment known in the Nordic countries.

Brand names for the new integrated energy systems in $\mathrm{CO}_{2}$ recovery plants are "LiquiVap" (Haffmanns, NL) and "ReVap" (UNION, DK). The "ReVap" system is described further in this chapter as a new BAT candidate.

\subsection{Applied processes and techniques}

A standard brewery $\mathrm{CO}_{2}$ recovery plant consists of the several elements as shown in the figure. 


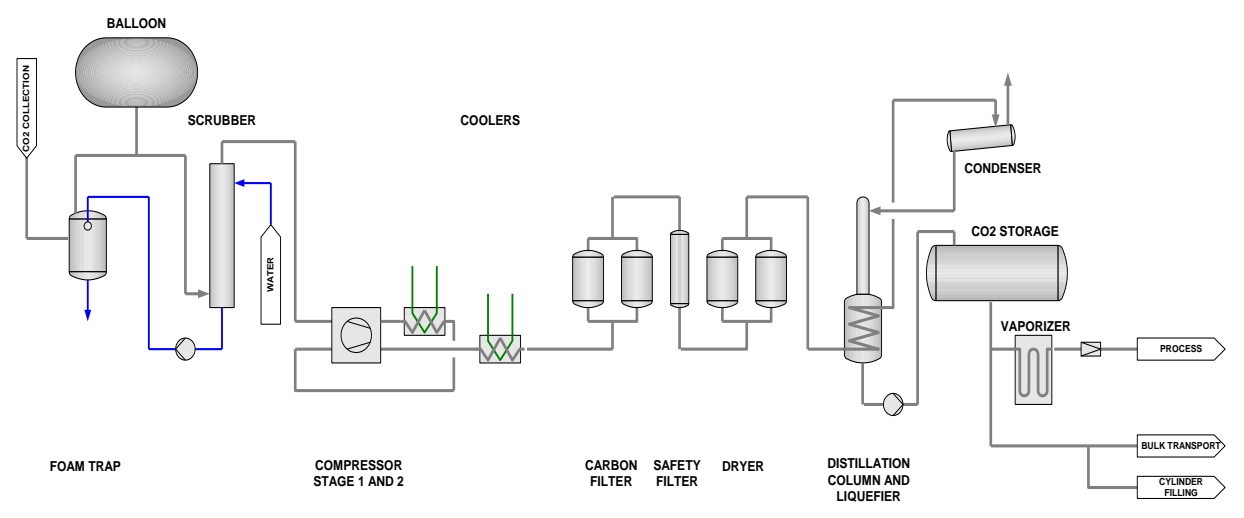

Figure 4.

The focus area for the new process is the vaporiser. This process step has classically been driven by supply of steam or just air to heat up the liquified $\mathrm{CO}_{2}$ arriving from the cold (minus $30{ }^{\circ} \mathrm{C}$ ) $\mathrm{CO}_{2}$ storage. This implies both use of steam to evaporate $\mathrm{CO}_{2}$ and a potential cooling capacity loss from the evaporated, cold $\mathrm{CO}_{2}$.

In the new process, a "ReVap" evaporiser captures the cooling energy arising from evaporation of $\mathrm{CO}_{2}$ and passes this cold liquid $\mathrm{CO}_{2}$ through a heat exchanger, which cools down relatively warm glycol returning from glycol evaporators at points of use elsewhere in the brewery.

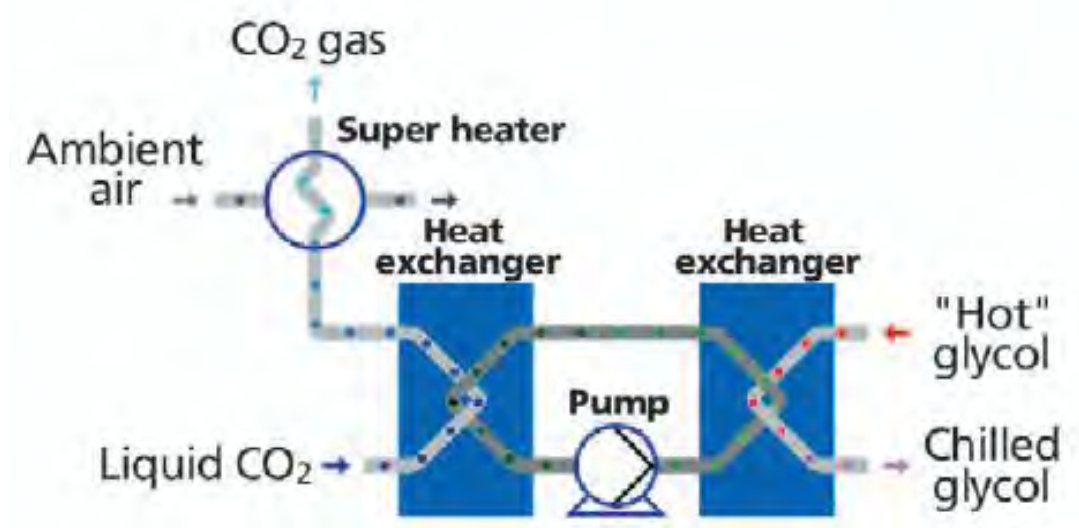

Figure 5: "ReVap", system from UNION $\mathrm{CO}_{2}$ plant producer, Denmark.

"ReVap" moves heat energy from the main brine system to the cold $\mathrm{CO}_{2}$.

As the vaporised $\mathrm{CO}_{2}$ would freeze the brine if the $\mathrm{CO}_{2}$ was heat exchanged directly with the brine, a strong glycol intermediate loop is installed. After evaporation the gaseous $\mathrm{CO}_{2}$ flows through an ambient super heater and exits to the point of use at about 10-20 ${ }^{\circ} \mathrm{C}$, depending on the ambient temperature. 


\subsection{Emissions and consumption figures}

"ReVap" is a closed cooling system, and no gasses are emitted to the atmosphere. The only emission is indirectly caused by the electrical energy usage. Consumption of electrical energy is assessed by the supplier to be relatively small.

\subsection{Environmental benefits}

The electrical energy efficiency of a cooling system determines if the installation is environmentally friendly. "ReVap's" environmental benefit arises from its ability to reuse the cooling energy from evaporation which otherwise in classical $\mathrm{CO}_{2}$-recovery plants gets lost.

"ReVap" is able to work along with the brewery's existing $\mathrm{NH}_{3}$ cooling system $\left(\mathrm{CO}_{2}-\mathrm{NH}_{3}\right)$. Heat coming from the recovery system is cooled by the brewery's $\mathrm{NH}_{3}$ cooling system. This way "ReVap" applies two "neglected" energy streams:

- heat released when liquefying $\mathrm{CO}_{2}$ gas and

- heat taken up when evaporating liquid $\mathrm{CO}_{2}$

"ReVap" simultaneously facilitates the liquefaction of incoming $\mathrm{CO}_{2}$ gas (from the fermenters) and vaporisation of incoming liquid $\mathrm{CO}_{2}$ (from the storage tanks).

\subsection{Applicability and feasibility}

The "ReVap" concept does not demand an existing $\mathrm{CO}_{2}$-recovery plant. "ReVap" may be considered installed, when:

- the brewery is already evaporating $\mathrm{CO}_{2}$ for distribution to points of use

- the brewery has got engineering staff to monitor plant running

- cooling energy produced from consumption of vaporized $\mathrm{CO}_{2}$ from "ReVap" can be utilised elsewhere in the brewery

- the brewery is able to process approximately $500 \mathrm{~kg} \mathrm{CO}_{2} / \mathrm{h}$ and run continuously, i.e. $>5.000$ h/year

\subsection{Cross-media effect}

The "ReVap" system illustrated in section 5.2 is shown with a pump to circulate the glycol. The energy consumption of this pump depends on the required flow. 
The cross-media effect is assessed by the system supplier to be insignificant $(<1 \%$ extra electricity consumption compared to the savings).

For future solutions the system suppliers are going to apply a thermo siphon, which will substitute the glycol pump completely. The thermo siphon will be working after an energy free natural convection system.

\subsection{Economics}

The "ReVap" concept relies on the efficient reuse of existing resources. The supplier has estimated that "ReVap" offers a saving equivalent to about $43 \%$ of a brewery's total annual $\mathrm{CO}_{2}$ production costs. The amount of energy saved is approximately $85 \mathrm{kWh}$ per $1000 \mathrm{~kg} \mathrm{CO}$ evaporated.

The electrical energy and maintenance costs are relatively small, although no data are yet available.

The supplier of the "ReVap" system has estimated the economic data given in the table below. The data shows a relatively short simple payback time.

Table 4.

\begin{tabular}{lr}
\hline Economic data (Ref.: UNION) & \\
\hline $\mathrm{CO}_{2}$ consumption & $2,000 \mathrm{~kg} / \mathrm{h}$ \\
Operation hours & $5,400 \mathrm{~h} / \mathrm{year}$ \\
Electricity cost & $0.065 € / \mathrm{kWh}$ \\
Fuel cost & $0.015 € / \mathrm{kWh}$ \\
Energy consumption for $\mathrm{CO}_{2}$ evaporation & $900 \mathrm{MWh} /$ year \\
Fuel saving with boiler efficiency = 0.9 & $1,000 \mathrm{MWh} /$ year \\
Electricity saving with refrigeration unit COP = 3 & $300 \mathrm{MWh} /$ year \\
Total savings & $34,500 € /$ year \\
"ReVap" unit costs & $30,000 €$ \\
Simple pay-back time & Approx. 11 months \\
\hline
\end{tabular}

\subsection{References}

Scandinavian School of Brewing, Master brewer curriculum: module 4 lectures, February-March, 2011.

http://www.union.dk and http://www.haffmans.nl 


\section{BAT Candidate no. 5 - Optimization of energy consumption in the brewhouse}

\subsection{Introduction}

Large sized breweries have increased focus on energy consumption, as energy is becoming a relatively higher proportion of total production costs. In a modern larger brewery the brewhouse may alone consume up to $50 \%$ of the total energy - if the brewhouse is classically configurated, and without heat recovery systems other than a wort cooler, which heats incoming brewing liquor in a counter flow.

This BAT candidate consists of 4 methods to reduce and optimise the consumption of energy in the brewhouse:

- Vapour condensation from wort kettle

- Increased degree of High Gravity Brewing

- Decrease of evaporation rate during wort boiling

- Mashing in at lower temperatures

\subsection{Applied processes and techniques}

\subsubsection{Vapour condensation from wort kettle.}

Many larger breweries have implemented some heat energy recovery systems other than re-use of the hot water generated from the wort cooler to a hot-water tank. Commercially available are now energy conservation systems designed to recover the heat arising from vapour from the boiling wort, as this vapour may generate heat when recondensed. An example of such a vapour-condensation plant from Huppmann is shown in the figure. The vapour condenser part is marked with a yellow box. 


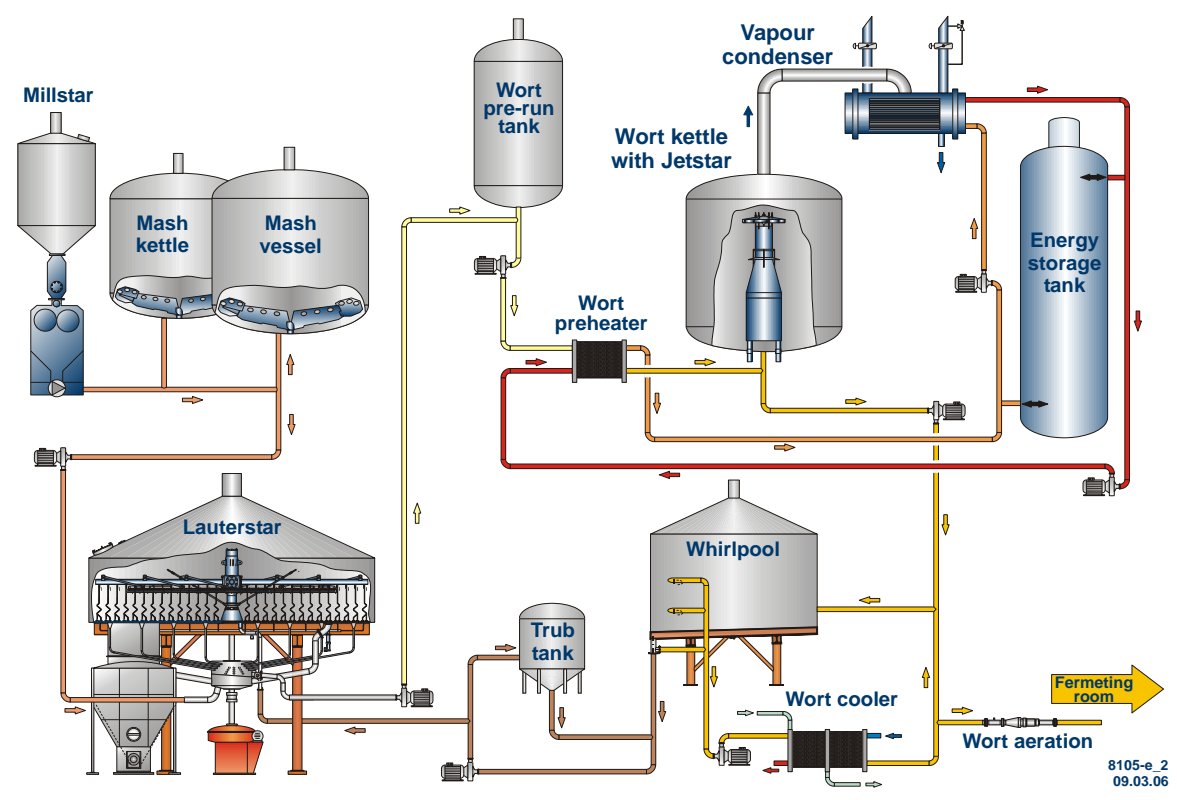

Figure 6: Energy recovery from vapour condensation, system Huppmann.

Such vapour condensation systems are able to recover approximately $75 \%$ of the condensation heat. The remaining some $25 \%$ gets lost in transfers, when boiled-off vapour is released to the open air at times during the process and via heat losses. Because of relatively high costs and the complexity of the system, it is only in the last 10 years that this solution has become economical attractive. This solution is often retrofitted into existing brewhouses.

\subsubsection{Increasing degree of High Gravity Brewing (HGB)}

Large breweries will normally already apply HGB at a rate of $20-30 \%$. This implies that a finished Pilsner of $10 \%$ Plato is brewed at an Original Gravity (OG) of $12-13 \%$ Plato. The driving force for HGB was years ago often a quick way of increasing capacity as less fermenters are needed with HGB and without compromising the quality of the beer. As energy costs rise more focus is given to savings for the needed wort volume to boil and for the fermenting beer volume to cool.

To day, it is possible to apply a HGB-degree of $40 \%$ for most beers and in most breweries. The increased amount of HGB-degree is directly proportional to saved boiling heat in the brewhouse and saved cooling energy at fermentation.

\subsubsection{Decrease evaporation rate during boil.}

Evaporation rates have gradually come down from $10 \%$ per hour to 6$7 \%$ per hour in most breweries. Recent tests at breweries have demonstrated, that the possible limit for needed evaporation is somehow low- 
er, and some breweries have documented that a $4 \%$ evaporation rate is sufficient.

Brewers are frequently monitoring the potential risks at reduced evaporation rates. Unwanted sulphur components (DMS) in the wort and cloudy finished beer are two well-known risks.

The reduced evaporation rate is proportional to saved heat energy.

\subsubsection{Mashing-in at higher temperatures.}

Breweries use different mashing diagrams (the temperatures used during the ca. 2 hours of the mashing process). Textbook mashing diagrams suggest mashing-in at $37^{\circ} \mathrm{C}$ or $50-52^{\circ} \mathrm{C}$, heating to $60-62^{\circ} \mathrm{C}$ and mashing off at $78^{\circ} \mathrm{C}$.

Traditional Infusion Mash 50 'C Mashing -in temperature

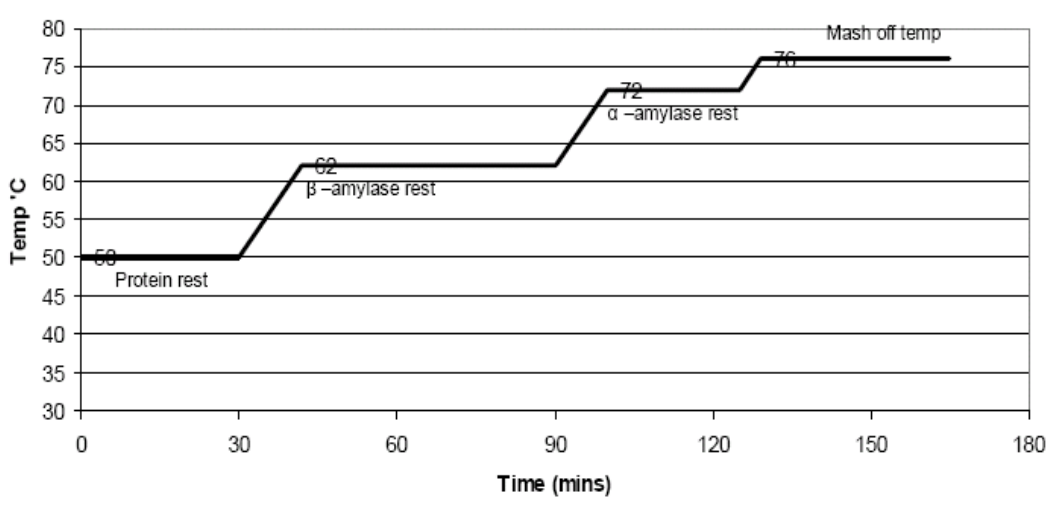

Figure 7: Classic infusion mashing diagram (Ref.: Scandinavian School of Brewing)

In recent years quality improvements have been achieved for malt used for mashing. One of the implications of this improvement is, that the need to keep temperature rests at i.e. $50^{\circ} \mathrm{C}$ has diminished, and some breweries have demonstrated, that they routinely are able to mash in at $60^{\circ} \mathrm{C}$. The consequence for heat energy is, that hot water from the wort cooling only needs to be blended with smaller volumes of cold water to produce $60^{\circ} \mathrm{C}$ mashing in water.

Brewers monitor the potential risks at increased mashing in temperatures. Insufficient protein- and beta-glucan degrading during mashing are most important risk, but possible to overcome by supply of malt of consistent high quality, i.e. with sufficient amounts of natural enzymes.

\subsection{Emissions and consumption figures}

Heat- and electricity consumption will be reduced introducing the described methods. For the 2 methods (5.3.2-5.3.3) proportional reductions are achieved. Energy savings will lead to reduced emissions. 


\subsubsection{Vapour condensation from the kettle}

Condensation of wort vapour is able to recover approximately $75 \%$ of the energy used for evaporation of wort.

\subsubsection{Increasing degree of High Gravity Brewing (HGB)}

Increased HGB-degree is providing proportionally heating energy savings, i.e. $25 \%$ HGB-degree will result in $25 \%$ heat energy savings in the wort kettle.

\subsubsection{Decreased evaporation rate during boil}

Reduced evaporation rate will lead to proportional savings of heat energy. If evaporation rate is reduced from $10 \%$ to $6 \%$, a $40 \%$ heat energy saving is expected.

\subsubsection{Mashing in at higher temperatures}

The exact heat energy saving by mashing-in at $60^{\circ} \mathrm{C}$ rather than at for example $50^{\circ} \mathrm{C}$ vary, but in most brewhouses a higher mashing-in temperature will imply, that hot water from the wort cooling only needs to be blended with smaller volumes of cold water to produce $60^{\circ} \mathrm{C}$ mashing-in water.

\subsection{Environmental benefits}

The environmental benefits are energy savings and reduced corresponding emissions.

Condensation of vapours from wort boiling will reduce emission of odour from breweries significantly.

\subsection{Applicability}

The methods 5.2.2-5.2.4 do not require direct capital investments at breweries, as the breweries are expected already to have a HGB plant for de-brewing the strong worts.

However, all 3 methods demand increased process supervision, as the margin between safe and unsafe process reduces.

If the brewery wants to reduce evaporation rate from 6 to $4 \%$, it should be able for each brew to control evaporation rate $+/-0.3 \%$, whereas this margin at $6 \%$ evaporation may be $+/-0.6 \%$.

For the increased mashing-in temperature it becomes critical, that supply of high quality malt is possible. Attention should be drawn to 
possible variations between crops from one year to the following year and to differences between suppliers.

\subsection{Cross-media effect}

None.

\subsection{Economics}

A classical brewhouse without vapour condensation consumes $50 \%$ of the brewery heat energy. Assuming that a brewhouse produces $12 \%$ Plato wort, mashes in at $50^{\circ} \mathrm{C}$ and evaporates $6 \%$ during wort boiling, the different methods may provide benefits as listed in the table.

Table 5.

Type of brewhouse heat recovery systems applied Heat proportion of brewery used in the brewhouse

Heat proportion of brewery used in the brewhouse
- best estimate

Classic brewhouse - only wort cooler

Brewhouse equipped with vapour condensation

Brewhouse additional equipped with $40 \%$ HGB

Brewhouse additionally equipped with only $4 \%$ wort

evaporation

Brewhouse additionally equipped with mashing in at

$60^{\circ} \mathrm{C}$

\subsection{References}

Scandinavian School of Brewing. Master brewer curriculum, module 1 lecture, August-September, 2010. http://brewingschool.dk/ 


\section{BAT Candidate no. 6 - The double malt kiln}

\subsection{Introduction}

Malting of barley consists of 3 main processes, steeping, germination and drying of which the drying process by far is the most energy intensive process.

In the drying process green malt from the germination process is dried from a water content of $45-47$ weight $\%$ to approx. 4.5 weight $\%$. At the same time the malt is heated from approx. $20^{\circ} \mathrm{C}$ to approx. $75^{\circ} \mathrm{C}$.

The intensive energy consumption is due to a high demand for electric power to drive the drying air through the malt and a high demand for heating to evaporate water and heat the malt to its final temperature.

\subsection{Applied processes and techniques}

The malt drying process takes place in two parts.

In the first "wet" part, so-called superficially combined water in the malt is evaporated at a high rate and the majority of the heat supplied to the process is used for evaporating water. This means that in this part of the process, the exhausted drying air holds a high humidity of more than $90 \%$ and a temperature around $25^{\circ} \mathrm{C}$. The drying air supplied to this first part of the process is kept at $60-65^{\circ} \mathrm{C}$.

In the second "dry" part of the drying process the chemically combined water is evaporated from the core of the grain through diffusion. The rate of evaporation is reduced considerably in comparison with the high rate in the first part of the process and continues to decline towards the end of the drying process.

With the decline in evaporation rate the heat supplied is increasingly used to heat the malt which also is needed to drive the diffusion process in the grains.

The malt temperature increases towards $75^{\circ} \mathrm{C}$ as the drying air temperature is increased stepwise to $85^{\circ} \mathrm{C}$. The exhaust air temperature increases to $77-78^{\circ} \mathrm{C}$ and the relative humidity of the exhaust air drops of steeply and end at $3-4 \%$.

The principle of the double malt kiln is shown in the figure below, where the principles of a parallel double malt kiln at the malt house "Sophus Fuglsang Export-Maltfabrik" in Haderslev, Denmark, are presented. The parallel double malt kiln operates with two malt kilns at 
slightly staggered intervals in "wet" mode and two malt kilns at slightly staggered intervals in "dry" mode instead of one in "wet" mode and one in "dry" mode.

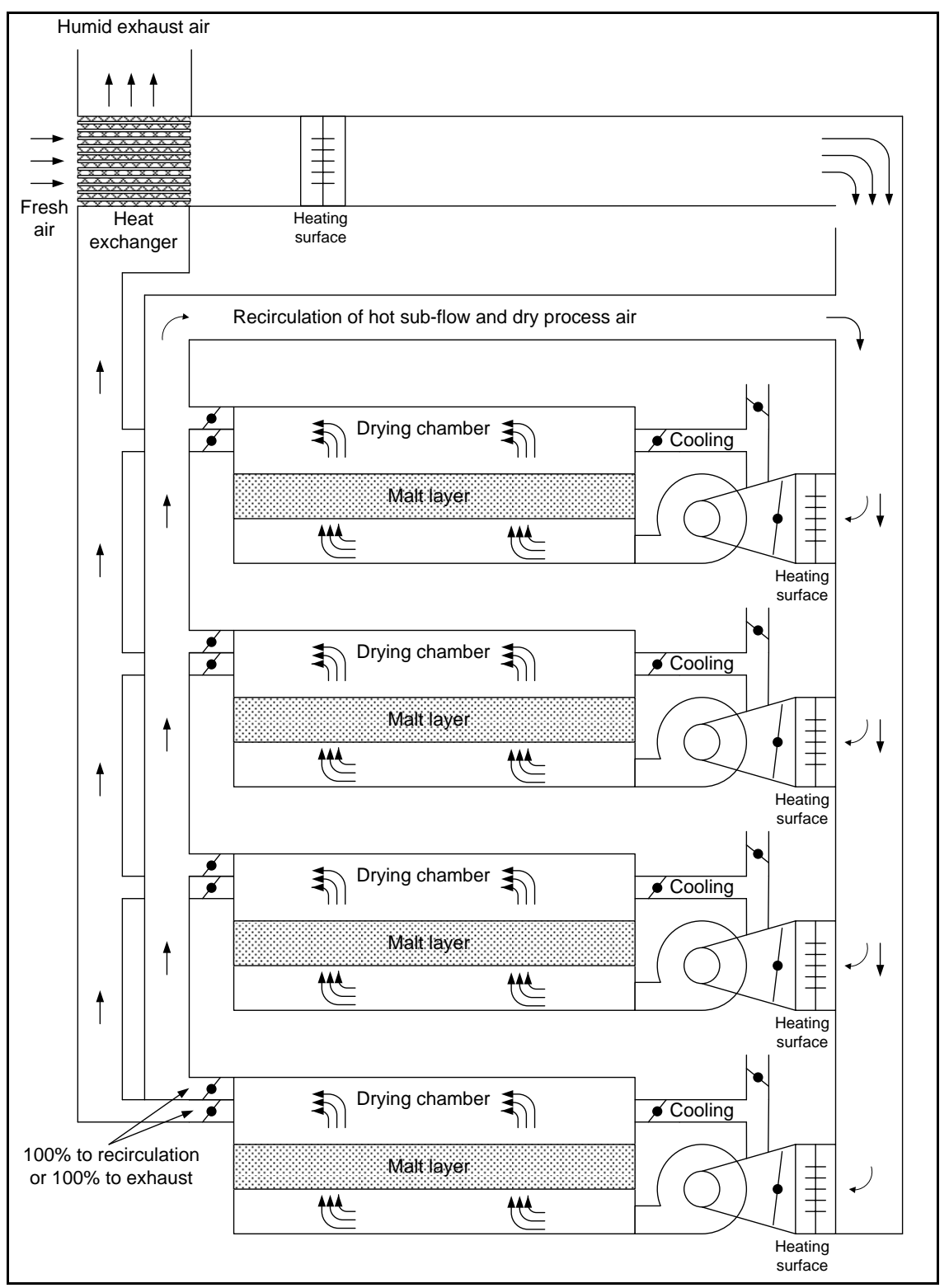

Figure 8: The Sophus Fuglsang malt kiln with two parallel double malt kilns

Fresh intake air is firstly heated in a glass tube heat exchanger by excess heat in the warm and humid exhaust air from the "wet" mode malt kiln(s). The process air is further heated over a heating surface before being mixed with hot and dry process air recirculated from the "dry" mode malt kiln(s). The mixture of fresh air and recirculated process air is now forced into the 4 drying chambers and through the malt layers by the blowers. 
Exhaust drying air is depending on "wet" or "dry" mode operation $100 \%$ exhausted to the surroundings through the glass tube heat exchanger respectively $100 \%$ recirculated.

The overall principle of the double malt kiln is to reuse the warm and dry exhaust air from the "dry" mode part of the process as direct air supply to the first part of the drying process and hereby reducing the heat demand for the process.

\subsection{Emissions and consumption figures}

Sophus Fuglsang Export-Maltfabrik operates a double malt kiln at their Haderslev malt house and single malt kiln at their Thisted malt house which are fully comparable in terms of the raw material (barley) processed and the type, quality and specifications of the final malt product as well as comparable in terms of weather conditions.

These outer circumstances are very import to consider when comparing the energy efficiency of different malt kilns as variations in these has a significant impact on energy consumption.

Sophus Fuglsang Export-Maltfabrik has decided not to provide specific energy consumption but only relative consumption data between the two malt houses.

- Heat consumption based on primary energy (natural gas) used the heat supply system: $20 \%$ lower in double malt kiln than in single malt kiln

- Power consumption from the power grid: $20 \%$ higher in double malt kiln than in single malt kiln

\subsubsection{Heat supply to the malt kiln}

The double malt kiln presents a very favourable opportunity to install a gas engine operating at combined heat and power mode in the malt house.

The reason for this is a constant high power and heat demand as one malt kiln is always in operation in comparison with a single malt kiln which needs to be emptied and filled up again once every 24 hours.

The constant high demand for power and heat makes it very favourable to utilize waste heat from the oil cooler and the turbo intercooler as well as surface heat losses from the engine and the engine exhaust stack, which can be routed through the air intake manifold. Waste heat recovery from the gas engine is according to the malt house capable of providing savings of $20 \%$ of the total heat consumption of the malt kiln.

There are similar opportunities to utilize waste heat from a gas engine as heat supply to the single malt kiln, however not as favourable as for the double malt kiln. 
A part of the better energy economy of the double malt kiln compared to the single malt kiln is due to operation of a gas piston engine as combined heat and power plant for the malt house.

\subsection{Environmental benefits}

The heat consumption is approx. 12 times larger than the electricity consumption for the double malt kiln. Hence the $20 \%$ lower heat consumption is significantly larger than the $20 \%$ increase in power consumption.

The environmental benefit of the double malt kiln is solely reduced energy consumption in comparison with the traditional single malt kiln.

As no specific energy figures have been disclosed for the double malt kiln no exact environmental benefits can be provided.

\subsection{Applicability}

The drying process of the malting process is highly affected by temperature and humidity.

The warmer and more humid the fresh air supplied to the process becomes, the less ability to absorb and carry water out of the malt drying process.

Very cold fresh air is however not suitable as the increased water absorption potential due to a low water content of the fresh air cannot make up for the substantially higher heat consumption required to heat the fresh air to the process temperature of $60-85^{\circ} \mathrm{C}$. This is true even though the malt kiln is equipped with a glass tube heat exchanger to transfer heat from the warm and humid exhaust air to the fresh intake air.

\subsection{Cross-media effect}

The power consumption is approximately $20 \%$ higher in a double malt kiln than in a single malt kiln. The power is at this malt house supplied from the power grid. Other Scandinavian malt houses are producing heat and power by own combined heat and power plant.

\subsection{Economics}

As no exact figures are provided for the reduced energy consumption connected with the double malt kiln, the economics of the double malt kiln compared to the single malt kiln cannot be given. 
However, it is widely known in the malting business that the double malt kiln offers a much better energy economy than the single malt kiln.

\subsection{References}

Sophus Fuglsang Export-Maltfabrik, Denmark. www.fuglsang.dk 



\section{BAT Candidate no. 7 - Use of non-fossil fuel based energy at malt house via district heating}

\subsection{Introduction}

Malt houses are consuming large amount of energy in the drying process. A Nordic malt house has introduced a partly non-fossil fuel solution to reduce energy consumption and introduce consumption of non-fossil fuel. The technique is referred to as district heating and the energy is supplied by an external energy plant situated outside the malt house.

Integration of a company energy supply system with an external network of district heating producers is also possible the other way around. Excess energy can be sold to an external energy supplier, if the amount of energy is sufficient, production is not fluctuating much, the district heating network is in place and there is a need for the produced energy.

\subsection{Applied processes and techniques}

District heat is produced by a local energy plant using different fuels: $55 \%$ biomass (wooden chips), 25\% waste and as a supplement fossil fuel (oil and natural gas).

District heat at $120^{\circ} \mathrm{C}$ is used to heat the inlet air to the malt kilns. The company used before natural gas heater.

The malt house uses triple kiln malting. The batch is divided into two withering kilns for the first kilning step. In the final kilning the batch is placed into one curing kiln. The hot outlet air from the final kiln is used as hot inlet air to the first kilns. The warm outlet air from the first kilns is heat exchanged with glass air-to-air heat exchangers to heat the incoming air to the kilns.

\subsection{Emissions and consumption figures}

The malt house has recorded data from two different malt towers used at the same time with different process heat sources. The heat consump- 
tion for the two malt processes is given in the table below. The malt house has concluded, that district heating is more effective than natural gas in the two different malt processes. $15 \mathrm{kWh} /$ ton or approximately $3 \%$ heat energy is according to the malt house saved by use of district heating compared to use of natural gas.

Table 6.

\begin{tabular}{llr}
\hline Malt process & Fuel & Heat consumption \\
\hline Malt tower 1 & Natural gas & $560 \mathrm{kWh} / \mathrm{ton}$ \\
Malt tower 2 & District heating & $545 \mathrm{kWh} / \mathrm{ton}$ \\
\hline
\end{tabular}

Electrical energy is similarly lower ( $5 \mathrm{kWh} /$ ton) for district heating compared to use of natural gas. Pumps are operated by the local energy plant, which is accounting for the electricity consumption.

The circulation pumps of the malt house are only in use during production stops.

The $\mathrm{CO}_{2}$ emission reduction is calculated to $70 \%$ shifting from natural gas to district heating as energy source.

\subsection{Environmental benefits}

Replacing onsite fuel use with district heating can be considered as an energy efficiency improvement, since district heat from combined heat and powers stations can be seen as more efficient way of utilising fuel energy than individual energy production. The indirect environmental benefit of the BAT candidate is a significant reduction in $\mathrm{CO}_{2}$ emission from substitution of the majority of consumed fossil fuel with non-fossil fuel. The process modifications offer also other minor energy savings.

\subsection{Applicability}

Access to district heating network is necessary. In order to obtain the $\mathrm{CO}_{2}$-emission reduction, the district heating need to be based on nonfossil fuels as the main energy source.

\subsection{Cross-media effect}

Natural gas (NG) is substituted by a fuel mixture consisting of $55 \%$ biomass (wood chips), $25 \%$ waste and approximately $20 \%$ oil and NG.

The fuel mix from the supplier leads to an emission of $0.062 \mathrm{~kg} \mathrm{CO}_{2}$ per kWh (calculated by Viking Malt according to instructions from REKO - a Swedish quality system for district heating). Since the NG leads to an emission of $0.205 \mathrm{~kg} \mathrm{CO}_{2}$ per $\mathrm{kWh}$ the $\mathrm{CO}_{2}$ emission reduction is calculated to $70 \%$. 


\subsection{Economics}

The malt house has observed a financial saving of approximately $32 \%$, when district heating was introduced to tower 2 and compared with costs of running tower 1 with natural gas as the energy source (2005).

The energy prices are fluctuating with time.

\subsection{References}

Viking Malt, Halmstad, Sweden. http://www.vikingmalt.com/en 



\section{BAT Candidate no. 8 - Brewery surplus yeast, rest beer and soft-drinks for bioethanol feedstock}

\subsection{Introduction}

More than $80 \%$ of the waste products from breweries can be reused. The majority of the bio-waste products (spent grain and yeast) are used as animal feed. Sugar liquids and alcohol containing beer waste fractions are normally disposed to the wastewater system.

A new technology developed in Finland, which can be seen as an alternative disposal method, can turn surplus yeast, rest beer and softdrinks into bioethanol, animal feed and $\mathrm{CO}_{2}$. Integrated bioethanol plant can also utilize bakeries and supermarkets bakery biowaste to compliment brewery waste to increase the fermentation production and increase the $\mathrm{CO}_{2}$-production.

The new technology, referred to as Etanolix $\AA$ evaporates alcohol from yeast and rest beer. Non-alcoholic waste-streams are fermented together with local bakery and supermarket bakery waste. $\mathrm{CO}_{2}$ from fermentation process is lead to Hartwall brewery for soft-drink production. The Etanolix® process produces liquid animal feed as by-product, which is sold to local farms.

\subsection{Applied processes and techniques}

Surplus yeast is lead into Etanolix® process, which is evaporated and alcohol is separated from yeast. The remaining fraction is sold to local farms as liquid animal feed.

Harwall is also able to discharge rest beer and liquid waste from softdrink production into Etanolix®-plant, where the sugars are fermented into ethanol by continuous fermentation process. Typically rest beer is evaporated and non-alcoholic waste liquids are diluted with bread to make it liquid format. This saves fresh water consumption at ethanol plant. Carbon dioxide is captured during the fermentation process, which is reused in Hartwall's soft-drink production.

St1's Etanolix ${ }^{\circledR}$ concept is based on dispersed production where the production and dehydration of bioethanol are separated. Etanolix $®$ 
units turn biowaste and side-products from the food processing industry into $85 \%$ ethanol. The ethanol is then transported to central dehydration unit, where the remaining water is evaporated by membrane technology. When alcohol reaches $99.8 \%$, it is ready to be mixed with petrol without any additional processing.

An Etanolix ${ }^{\circledR}$ plant is integrated to Hartwall brewery in Lahti, Finland. There are currently five Etanolix® plants in Finland and one under construction. Two of these are integrated into food industry facility. The Etanolix ${ }^{\circledR}$ plant has a bioethanol production capacity on average of $1,000 \mathrm{~m}^{3}$ per year.

\section{Here's how it works}

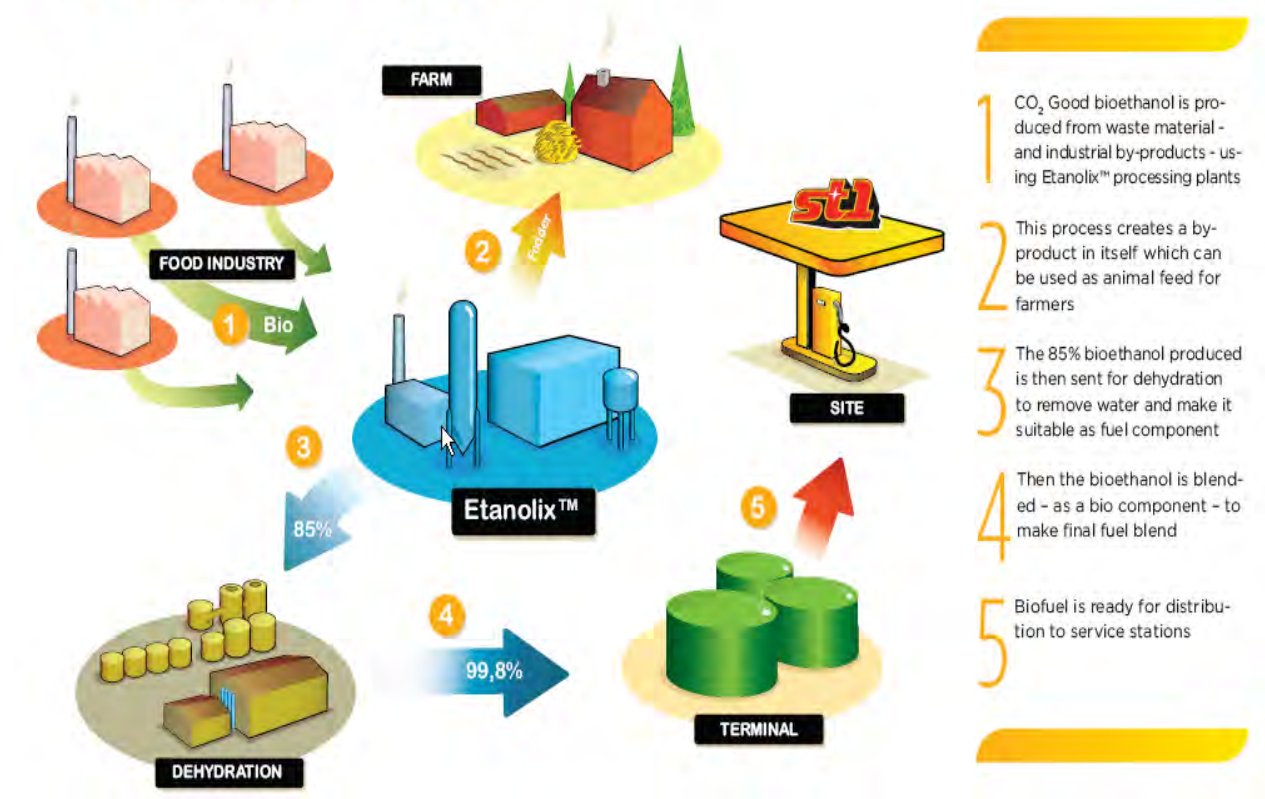

Figure 9.

Reference: St1 Biofuels Oy.

St1 is currently researching cellulosic based feedstocks for bioethanol production and they are also looking into spent grain. Spent grains are considered as low value products; however they are rich source of lignocellulose, which can be converted to fermentable sugars for production of bioethanol.

\section{Characteristics of Etanolix ${ }^{\circledR}$ plants:}

\section{Modular design}

Ready ensembled modules are transported to the plant location to be installed. Modular design enables easy and fast installation. 


\section{Continues fermentation and ethanol take off}

While sugar or starch based feedstock is fermented the ethanol is removed from the fermentation beer. This enables more efficient fermentation.

\section{Energy efficiency top priority}

St1's bioethanol production plants are very energy efficient, they use renewable energy and the end and by-products are produced with the same equipment and energy.

Overview of Brewery by-products and waste streams for bioethanol production:

\begin{tabular}{|c|c|c|c|}
\hline By-product (waste) & Out-puts, old & Process & Outputs, new \\
\hline Yeast & Animal feed & Evaporation & $\begin{array}{l}\text { Ethanol } \\
\text { Liquid animal feed fraction }\end{array}$ \\
\hline Rest beer & Wastewater & Evaporation & $\begin{array}{l}\text { Ethanol } \\
\text { Wastewater }\end{array}$ \\
\hline Rest softdrinks & Wastewater & Fermentation & $\begin{array}{l}\text { Ethanol } \\
\text { Wastewater } \\
\mathrm{CO}_{2}\end{array}$ \\
\hline Spent grain & Animal feed & Enzyme/fermentation & $(*)$ \\
\hline
\end{tabular}

$\left({ }^{*}\right)$ This feedstock is currently in R\&D-phase, and St1 has plans to utilise spent grain for bioethanol feedstock.

\subsection{Emissions and consumption figures}

No emission and consumption figures are available for the processes.

\subsection{Environmental benefits}

"Hartwall's goal is to be the most responsible supplier in the drinks business. Eve ry aspect of the brewery has been designed with environmental considerations in mind. The machinery and processes have been chosen on the basis of their water and energy consumption in particular, and the primary source of energy is natural gas. They also recycle a significant percentage of the packaging materials. The Etanolix®-concept allows Hartwall to make even more efficient use of organic waste.

In some areas it has become difficult to utilize brewery by-products, like spent grain and yeast as animal feed due to reduced number of farms and they need to transported long distances. Also, in many breweries rest beer overloads the wastewater systems. The Etanolix® concept is an alternative disposal method changing the waste streams into feedstock for bio-ethanol production.

Etanolix® concept supports EU biofuel's directive to promote sustainable bioethanol production.

Etanolix® concept allows by-product handing at brewery site: 
- No by-product transportation

- Able to utilize rest beer and soft-drinks

- Reduces load for waste-water system

- Still produces high quality animal feed

- Produces sustainable bioethanol

Due to the integration of Etanolix and the brewery Hartwall can also reuse the carbondioxide generated from Etanolix fermentation. Hartwall is also able to utilize the reject fractions from the brewery nano-filtration plant for Etanolix process as water. Saving in wastewater charges are based on the fact that earlier destroyed soft drinks and drinks rests were put into the sewage system. The wastewater charge is based on organic load of wastewater.

Integrated Etanolix-plant allows Hartwall to utilize their by-products at their site without feedstock transportation.

\subsection{Applicability}

The Etanolix ${ }^{\circledR}$ production units are built to near feedstock sources of fermentable waste. In the case of smaller brewery, the multilateral collaboration with local food industry companies will ensure that the bioethanol plant has access to sufficient volumes of feedstock and is able to operate efficiently and cost-effectively. Utilization of spent grain for bioethanol production will bring the required added feedstock for many smaller breweries. Sufficient amount of biowaste product must be available to make the bio-ethanol production efficient and cost-effective. Due to small scale and modular-design, plants are easy and speedy to build.

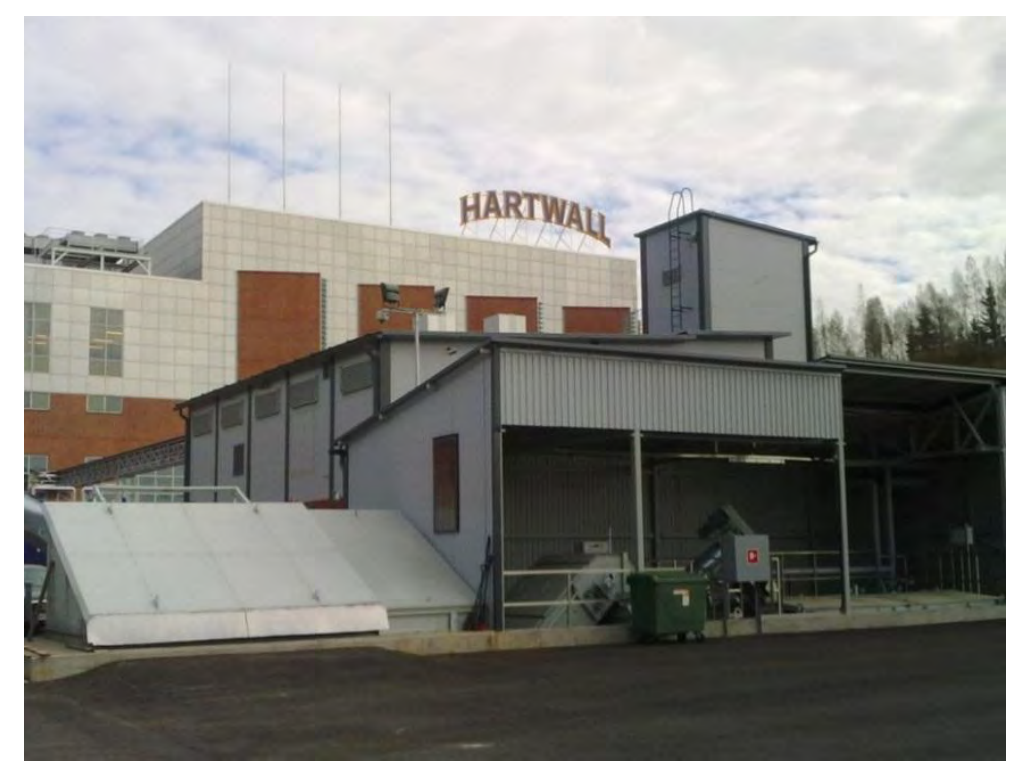

Photo 3: Etanolix-plant in front of Hartwall-brewery. 


\subsection{Cross-media effect}

Using the Etanolix® concept will change the waste media from the brewery into others.

Yeast will be transferred into liquid ethanol and a dryer spent yeast fraction. Alcoholic containing waste will be transferred into two other liquid fractions: ethanol and wastewater. Sugar liquid fractions are transferred into an alcoholic liquid fraction and a gaseous fraction $\left(\mathrm{CO}_{2}\right)$.

Some of the processes related to the Etanolix concept are energy demanding. St1 does not have available data on energy consumption and emission of green house gasses (GHG) from the Etanolix plant. St1 has a LCA study ongoing at the moment.

However, ST1 expects to comply with the Renewable Energy Directive 2009/28/EC, which establishes a common framework for the use of energy from renewable sources in order to limit greenhouse gas emissions and to promote cleaner transport. The Directive takes into account energy from bio-fuels and bio-liquids. Bio-liquids should contribute to a reduction of at least $35 \%$ of greenhouse gas emissions in order to be taken into account. From 1 January 2017, the share in GHG emissions savings will be increased to $50 \%$.

St1 is confident that Etanolix already to day meets the requirements in the Directive and that the Etanolix plant will do it in 2017 with 50\% savings due to the following arguments (ref.: St1 Biofuels Oy):

- The Etanolix process is energy efficient

- The process is using by-products for ethanol production, which eliminates emissions from farming, harvesting and fertilization

- The process eliminates emissions from feedstock transportation

- St1 has established a network of fuel stations in Finland. When possible, fuel-trucks delivering fuel to stations pick up ethanol-load from plant on return journey. The share of transport reduces $\mathrm{CO}_{2}$ emissions even further

- $\mathrm{CO}_{2}$ generated during the fermentation process is utilized in softdrink production in the brewery, which replaces $\mathrm{CO}_{2}$ produced from a traditional fossil source

\subsection{Economics}

The main economic advantage to brewery is the possibility to collect $\mathrm{CO}_{2}$ from Etanolix fermentation and so reduce the amount of $\mathrm{CO}_{2}$ bought (note that the brewery is producing also unfermented carbonated drinks, app. $50 \%$ of $\mathrm{CO}_{2}$ is bought). Also while BOD load on wastewater is lower due to drinks and drinks rests going to Etanolix and not to sewer almost as big savings are achieved as from $\mathrm{CO}_{2}$ collection. In this case 
one has to remember also that the capacity of the municipal wastewater plant is limited.

\subsection{References}

Oy Hartwall Ab and St1 Biofuels Oy. http://www.hartwall.fi and http://www.st1.eu 


\section{Emerging Techniques}

Emerging techniques are BAT not yet fully developed, tested and documented. Consequently, no long-term and reliable data on consumption figures and emissions are available. Some of these BAT candidates will most likely be relevant as BAT candidates in the near future.

Table 8.

\begin{tabular}{cll}
\hline S.N. & Emerging Techniques & Environmental benefits \\
\hline 9.1 & External cooling of fermentation tank. & $\begin{array}{l}\text { Energy saving } \\
\text { Saving energy, water and chemicals }\end{array}$ \\
\hline .2 & Electro Chemical Activation (CIP) & \\
\hline
\end{tabular}

\subsection{External cooling of the fermentation tank}

External cooling of the fermentation tank is a technology that can provide more efficient cooling of the fermentation process, improve the fermentation process and lead to reduced fermentation time and reduced energy consumption.

The idea of the technology is to replace traditional inefficient jacket cooling of the fermentation tank with more efficient cooling in an external heat exchanger where the beer is forced through by a circulation pump.

External cooling can be combined with a new fermentation mixer system called Iso-mixer. These new BAT candidates are implemented in some Nordic breweries. Unfortunately, no data has been available for the project.

Cooling of a fermentation tank is traditionally carried out by jacket cooling. As the traditional fermentation tank is not equipped with any kind of mechanical agitation, mixing of the beer is only driven by the gravitational forces of cooler beer sinking to the bottom of the tank along the cooled tank walls and warmer beer in the centre of the tank rising to the top of the tank, see the figure on next page. 


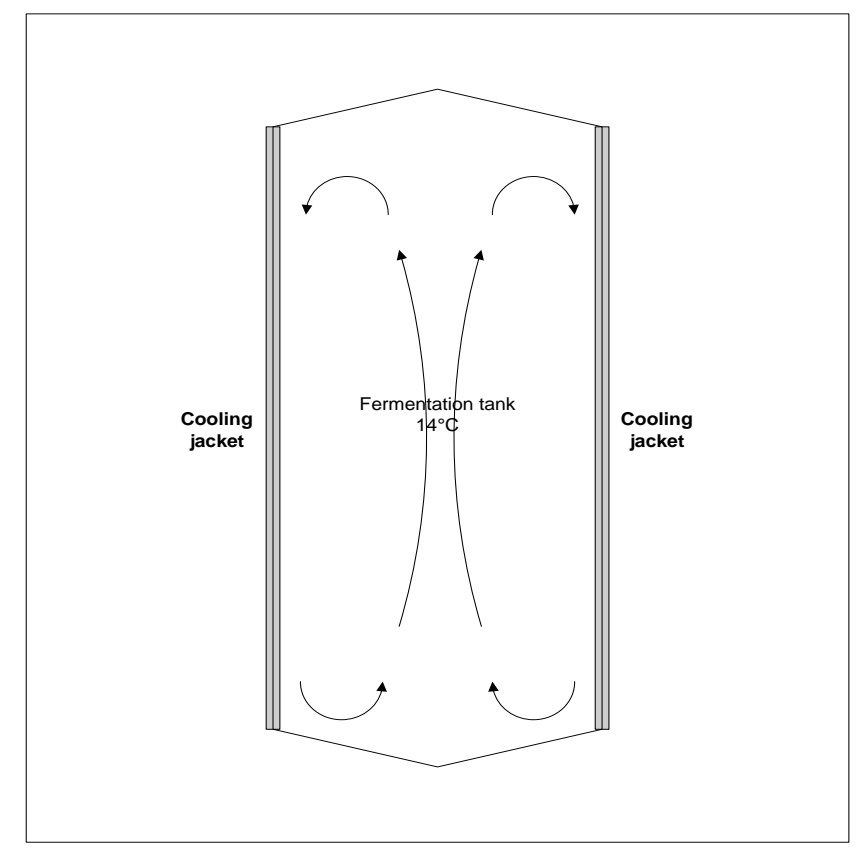

Figure 10: Beer circulation in traditional fermentation tank with jacket cooling.

As the only driver in the tank is gravitational forces, the flow velocity down the smooth vertical stainless steel wall will be rather low and the corresponding heat transfer coefficient from convection (natural convection) will be low.

As the heat transfer coefficient due to conduction (k-value) through a stainless steel wall also is low, the overall heat transfer coefficient $U$ becomes rather poor which means that jacket cooling of the fermentation tank is rather ineffective.

In order to remove the heat generation from the fermentation process the temperature of the cooling media in the jacket typically needs to be $-5^{\circ} \mathrm{C}$.

\section{Applied processes and techniques}

The principle of external cooling of the fermentation tank is shown in the figure below. 


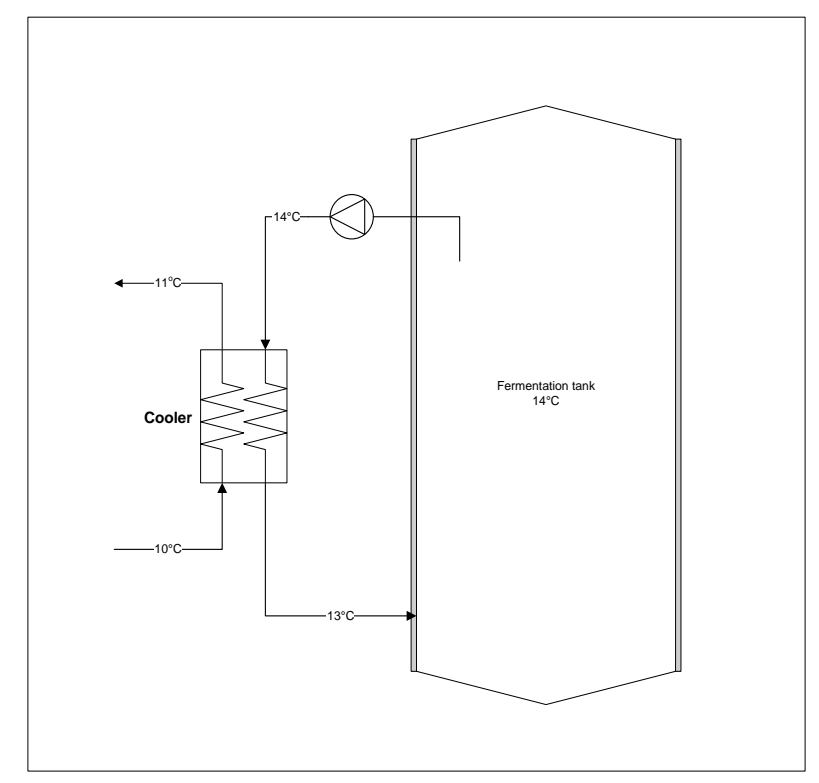

Figure 11: External cooling of fermentation tank.

The advantage of this cooling technology in comparison with the jacket cooling technology is the much larger overall heat transfer achievable with an external heat exchanger than with jacket cooling and an arbitrary size of the heat transfer area which no longer is fixed to the tank geometry.

The heat transfer rate is primarily achieved by mechanically increasing the flow velocity over the heat transfer surface by a pump and by improving the conduction heat transfer coefficient by using very thin plates between beer and cooling media.

The heat transfer surface area is a matter of heat exchanger designed. A plate exchanger, for instance, has a very large heat transfer surface area compared to the total size of the heat exchanger.

The external cooling system results in a smaller temperature difference of the cooling media and enables a higher cooling media temperature which means that the evaporation temperature of the refrigerant in the cooling plant can be increased leading to improved energy efficiency and increased capacity of the cooling plant.

In addition to this environmental advantage, the forced agitation provided by circulating the beer leads to a better mixing of yeast and beer in the fermenting process which leads to a faster fermentation process.

Finally, external cooling can be used to speed up the final cooling down process where the beer is cooled from $14^{\circ} \mathrm{C}$ to $-1-2^{\circ} \mathrm{C}$.

\subsection{Electro Chemical Activation (CIP)}

A new technique to clean and disinfect equipment within the food industry has been introduced during the last years: Electro Chemical Activation. The cleaning and disinfection agents are produced at the site 
through an electrochemical process from Sodium Chloride (table salt) solution. Some breweries in the Nordic countries have introduced ECA recently as a substitution for conventional CIP cleaning.

On the cathode side $\mathrm{OH}^{-}$ions are formed, which are used for the cleaning purpose. On the Anode side $\mathrm{Cl}_{2}$ is formed. $\mathrm{OH}^{-}$ions and $\mathrm{Cl}_{2}$ can react and form hypochlorous acid ( $\mathrm{HClO})$, which act as a disinfectant.

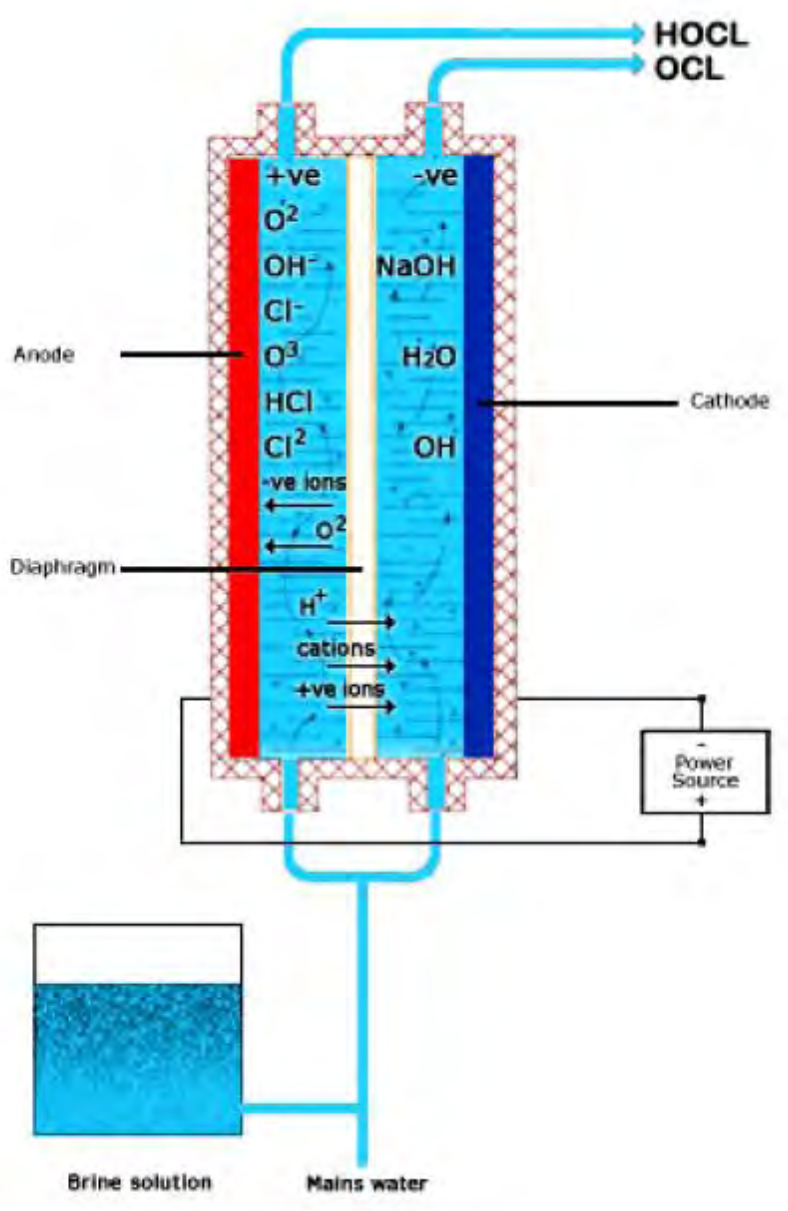

Figure 12.

Cleaning and disinfection take place with the use of a cold solution.

Savings on energy consumption, chemicals and maybe water consumption are achieved. The operation time has not yet allowed a full documentation of this new BAT candidate. One brewery has indicated that the annual energy consumption may be reduced by approximately $100,000 \mathrm{KWh}$ per production line. The cost of chemicals will for sure be significantly reduced. 


\section{Sammenfatning}

Rapporten præsenterer nye BAT (Bedste Tilgængelige Teknik) kandidater for større og IPPC relevante bryggerier, malterier og læskedrik producenter identificeret i de nordiske lande.

Større og IPPC relevante bryggerier har en produktionskapacitet på mere end 300 tons per dag eller 1,100,000 hl per år. I de nordiske lande findes der henholdsvis 7 og 13 bryggerier og malterier.

Denne rapport er forberedt som et fælles Nordisk bidrag til den Tekniske Arbejdsgruppe og foreslås anvendt, når reviewet af BREF dokumentet for Fødevare, Drikkevare og Mejeriindustien fra 2006 skal igangsættes.

Spredning af nye ideer og teknologier sker oftest gennem leverandører og konsulenter. I nogle tilfælde går denne spredning forholdvis hurtigt. På den anden side er den tid, der går fra en ide og teknik er introducret og til den er fuldt afprøvet og dokumenteret, ofte en del længere. Primært grundet disse omstændigheder har det været en udfordring at udvælge de løsninger, som er tilstrækkelig testet og dokumenteret og som ikke er for kendte af for mange bryggerier. Identifikationen af nye BAT kandidater i denne rapport er derfor sket ud fra kriteriet, at en ny BAT kandidat primært skulle have sin oprindelse i et af de nordiske lande.

BAT beskrevet i denne rapport er relateret til en række ressourcebesparende og optimeringsløsninger, som f.eks. substitution af råvarer og processer, besparelser på energi, vand og kemikalier, brugen af ikke fossile brændseler samt produktion af alternativ energi ud fra bryggeriets spildstrømme.

8 potentielt nye BAT kandidater og 2 mulige fremtidige teknikker er indeholdt i rapporten. De nye BAT kandidater er:

- Ølbrygning på $100 \%$ byg (råvare substitution og energibesparelse)

- Ølbrygning på byg (vand- og energibesparelse)

- ISO-mixer fermenteringssystem (produktivitetsøgning)

- Integreret energy system i $\mathrm{CO}_{2}$-genvindingsanlæg (Liquivap, energibesparelse)

- Optimeret energiforbrug i bryghus (reduktion og optimering af energiforbrug)

- Dobbelt malt kiln (energibesparelse)

- Brug af ikke fossil brændsel i bryghus (energibesparelse og alternativ energianvendelse)

- Brug af overskudsgær, øl og læskedrik som råvare for bioethanol produktion (reduktion af spildevandsbelastning og energibesparelse) 
De 2 mulige fremtidige teknikker er:

- Ekstern køling af fermenteringstank (energibesparelse)

- Elektrokemisk aktivering (besparelse af kemikalier, energi og vand)

Alle BAT kandidater er beskrevet ved følgende parametre: Anvendte processer og teknikker, emissions- og forbrugsdata, miljømæssige fordele, teknisk anvendelighed, tværgående miljøpåvirkninger (cross-media effects), økonomiske forhold samt referencer. 
Ved Stranden 18

DK-1061 Copenhagen K

www.norden.org

\section{Input to TWG on BAT Candidates for Breweries}

The report presents new BAT (Best Available Techniques) candidates for larger breweries, malting companies and soft drink producers identified within the Nordic brewery sector. The report is prepared as a joint Nordic contribution to the Technical Working Group and is proposed to be used when a review of the BREF for Food, Drink and Milk Industries from 2006 is launched.

Larger and IPPC relevant breweries have a production capacity exceeding 300 tons per day or $1,100,000 \mathrm{hl}$ per year. The number of larger breweries and malting companies in the Nordic countries is 10 companies.

8 potential new BAT candidates and 2 emerging techniques are included in the report and all candidates have their origin in the Nordic countries. The BAT described in the report are related to a number of resource saving and optimisation solutions, e.g. like substitution of raw materials and processes, energy and water savings plus production of renewable energy based on brewery waste and side-products.

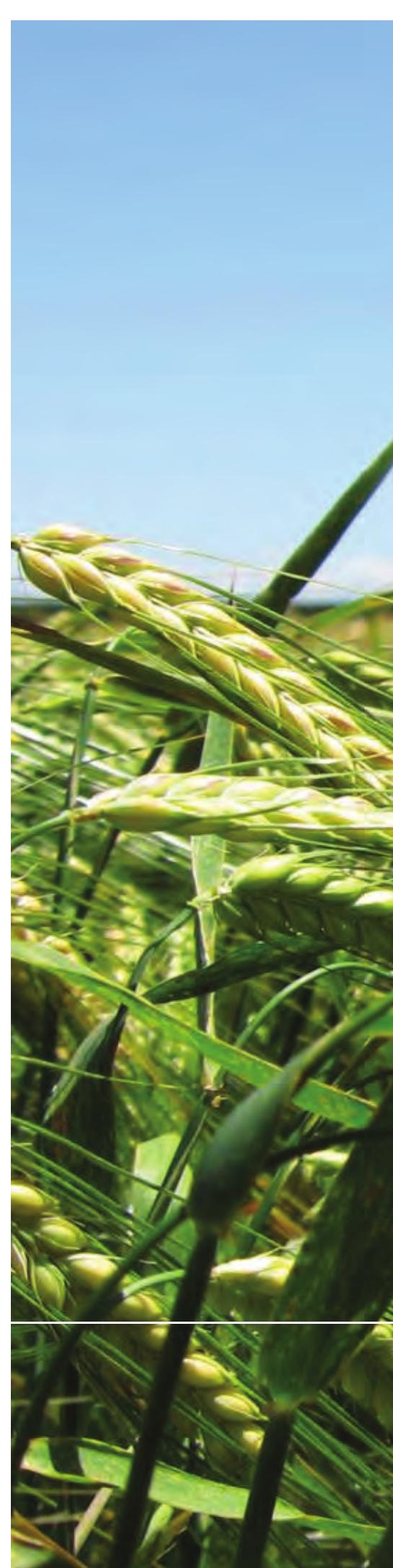

